\title{
Paleovegetational Reconstruction and Implications on Formation of Oil Shale and Coal in the Lower Cretaceous Laoheishan Basin (NE China): Evidence from Palynology and Terpenoid Biomarkers
}

\author{
Yu Song ${ }^{1, *}$, Kai Zhu ${ }^{1}$, Yinbo Xu ${ }^{2, *} \mathbb{D}$, Qingtao Meng ${ }^{3}$, Zhaojun Liu ${ }^{3}$, Pingchang Sun ${ }^{3}$ and Xiang Ye ${ }^{1}$ \\ 1 Key Laboratory of Tectonics and Petroleum Resources, China University of Geosciences, Ministry of \\ Education, Wuhan 430074, China; zk_cug123456@163.com (K.Z.); yexiang420@163.com (X.Y.) \\ 2 Oil and Gas Survey, China Geological Survey, Beijing 100083, China \\ 3 College of Earth Sciences, Key Laboratory for Oil Shale and Paragenetic Minerals of Jilin Province, \\ Jilin University, Changchun 130061, China; mengqt@jlu.edu.cn (Q.M.); liuzj@jlu.edu.cn (Z.L.); \\ sunpc@jlu.edu.cn (P.S.) \\ * Correspondence: songyu@cug.edu.cn (Y.S.); xuyinbo87@126.com (Y.X.)
}

\section{check for} updates

Citation: Song, Y.; Zhu, K.; Xu, Y.; Meng, Q.; Liu, Z.; Sun, P.; Ye, X. Paleovegetational Reconstruction and Implications on Formation of Oil Shale and Coal in the Lower Cretaceous Laoheishan Basin (NE China): Evidence from Palynology and Terpenoid Biomarkers. Energies 2021, 14, 4704. https://doi.org/ $10.3390 /$ en14154704

Academic Editor: Reza Rezaee

Received: 18 June 2021

Accepted: 27 July 2021

Published: 3 August 2021

Publisher's Note: MDPI stays neutral with regard to jurisdictional claims in published maps and institutional affiliations.

Copyright: (c) 2021 by the authors. Licensee MDPI, Basel, Switzerland. This article is an open access article distributed under the terms and conditions of the Creative Commons Attribution (CC BY) license (https:// creativecommons.org/licenses/by/ $4.0 /)$.

\begin{abstract}
In some cases, the oil shale deposited in shallow lakes may be genetically associated with the coal-bearing successions. Although paleovegetation is an important controlling factor for the formation of oil shale- and coal-bearing successions, few studies have focused on their joint characterization. In this study, a total of twenty-one oil shale and coal samples were collected from the upper member of the Lower Cretaceous Muling Formation $\left(\mathrm{K}_{1} \mathrm{ml}_{2}\right)$ in the Laoheishan Basin, and investigated for their bulk geochemical, maceral, palynological, and terpenoid biomarker characteristics, in order to reconstruct the paleovegetation and reveal its influence on the formation of oil shale and coal. The $\mathrm{K}_{1} \mathrm{ml}_{2}$ is subdivided into lower, middle, and upper units. The studied oil shale samples from the lower and upper units display a high ash yield $\left(\mathrm{A}_{\mathrm{d}}\right)$, low total organic carbon (TOC) and sulfur (S) contents, and limited hydrocarbon generation potential. The studied coal samples from the middle unit are characterized by low $\mathrm{A}_{\mathrm{d}}$, and high TOC and low $\mathrm{S}$ values, and show significant hydrocarbon generation potential. The paleovegetation during the formation of the lower unit was dominated by mire vegetation, such as shrubs (e.g., Lygodiaceae, Schizaeaceae), tree ferns (e.g., Dicksoniaceae/Cyatheaceae), and coniferous trees (e.g., Podocarpaceae). In the middle unit interval, the paleovegetation was represented by highland vegetation (Pinaceae and Araucariaceae) and peat-forming coniferous plants (e.g., Podocarpaceae, Cupressaceae/Taxodiaceae). Various vegetation, such as herbs (e.g., Osmundaceae), shrubs (e.g., Schizaeaceae), and coniferous trees (e.g., Podocarpaceae) was prosperous during the upper unit interval. Coniferous trees could provide abundant hydrogen-rich materials (e.g., resins) to the mire/lake, which may elevate the hydrogen content in peat/lake sediments, and finally result in higher hydrocarbon generation potential in the coal than in the oil shale. Therefore, the influence of paleovegetation on the formation of oil shale and coal should be fully considered when studying oil shale- and coal-bearing successions. The results also provide guidance for further exploration studies on oil shale and coal in northeast China.
\end{abstract}

Keywords: oil shale; coal; paleovegetation; palynology; terpenoid biomarkers

\section{Introduction}

Oil shale- and coal-bearing successions have been widely found around the world, such as the Fushun, Huadian, Meihe, Huangxian, Laoheishan, and Dachanggou basins in China [1-6], the Mae Tip Basin in Thailand [7], the Delbi-Moye Basin in Ethiopia [8], the Liard Basin in Canada [9], and the Beypazari and Seyitomer Basins in Turkey [10-12]. Joint exploration and development of oil shale and coal is a feasible option to raise energy utilization efficiency, and reduce costs and environmental pollution [13,14]. Multiple controlling 
factors are responsible for the formation of oil shale- and coal-bearing successions, including the paleoclimate, tectonic setting, paleoenvironment, and paleovegetation [5,12,15-22]. Among these, the influence of the paleovegetation on the formation of oil shale and coal has been rarely investigated because it was believed that oil shale was formed in the aquatic environment with a certain depth, and the organic matter mainly originated from aquatic organisms [23,24]. However, the oil shale interbedded with coal is generally deposited in shallow lakes, and contains a large proportion of terrestrial organic matter derived from land plants $[5,25]$. Therefore, revealing the influence of paleovegetation on the formation of oil shale and coal can not only improve knowledge of their formation mechanisms, but also provide guidance for their joint exploration and development.

In northeast China, oil shale- and coal-bearing successions are widely distributed through time and space; for example, the Eocene Yilan Basin and the Lower Cretaceous Laoheishan Basin [26,27]. Several oil shale and coal layers are developed in the Lower Cretaceous Muling Formation $\left(\mathrm{K}_{1} \mathrm{ml}\right)$ in the Laoheishan Basin, and the liptinite in both of these is dominated by resinite, sporinite, and cutinite, with only minor percentages of alginite ( $<1$ vol. \%, on a mineral matter-free basis; [5]). The liptinite composition suggests that land plants made a major contribution to the organic matter during the formation of oil shale and coal, making it an excellent example for this study. Moreover, few studies have been undertaken on this topic in the Laoheishan Basin, although the paleoenvironment, provenance and tectonic setting, and origin and occurrence of minerals and elements of oil shale and coal have been investigated in detail [5,27-29]. Therefore, the aims of this study were to (1) reconstruct the paleovegetation, and (2) reveal the influence of paleovegetation on the formation of oil shale and coal. To achieve these goals, oil shale and coal samples were collected from the Well N1 and determined for their ash yield, bulk geochemical parameters, spore-pollen assemblage, and terpenoid biomarkers.

\section{Geological Setting}

The Laoheishan Basin is an intermontane basin situated in the Xingkai Block, northeast China (Figure 1A,B). The basement surrounding the basin comprises Precambrian metamorphic rocks and Meso-Cenozoic volcanic rocks [30]. The basin covers an area of approximately $400 \mathrm{~km}^{2}$ and is filled with the Lower Cretaceous Muling Formation, Dongshan Formation, and Neogene Chuandishan Formation (Figure 1C,D). A thick basalt layer of the Neogene Chuandishan Formation is extensively developed in the central and southeastern parts of the basin. As a result, the Lower Cretaceous strata is only exposed in the northwest (Figure 1C).

The Lower Cretaceous basin fill is dominated by the Muling Formation, with the thickness decreasing southeastwards (Figure 1D). The Muling Formation can be further divided into two members: the lower member $\left(\mathrm{K}_{1} \mathrm{ml}_{1}\right)$ consists of conglomerate interbedded with sandstone and mudstone, and the upper member $\left(\mathrm{K}_{1} \mathrm{ml}_{2}\right)$ mainly comprises sandstone, siltstone, mudstone, coal, and oil shale, with limited conglomerate (Figure 2A). Therefore, the $\mathrm{K}_{1} \mathrm{ml}_{2}$ was selected as the target interval for this study.

Based on the lithological variation, the $\mathrm{K}_{1} \mathrm{ml}_{2}$ is further divided into lower, middle, and upper units (Figure 2B). The lower unit (from the bottom to $294 \mathrm{~m}$ ) consists of fine sandstone and siltstone interbedded with oil shale. The middle unit (294 to $201 \mathrm{~m}$ ) comprises conglomerate, and coarse to medium sandstone, developing several coal and oil shale layers. The upper unit (201 $\mathrm{m}$ to the top) is mainly composed of coarse to medium sandstone interbedded with siltstone and oil shale. Fossils of ferns are widely found in the lower and upper units, whereas possible gymnosperms (probably conifer remains) have been observed in the middle unit (Figure 2C-H). 


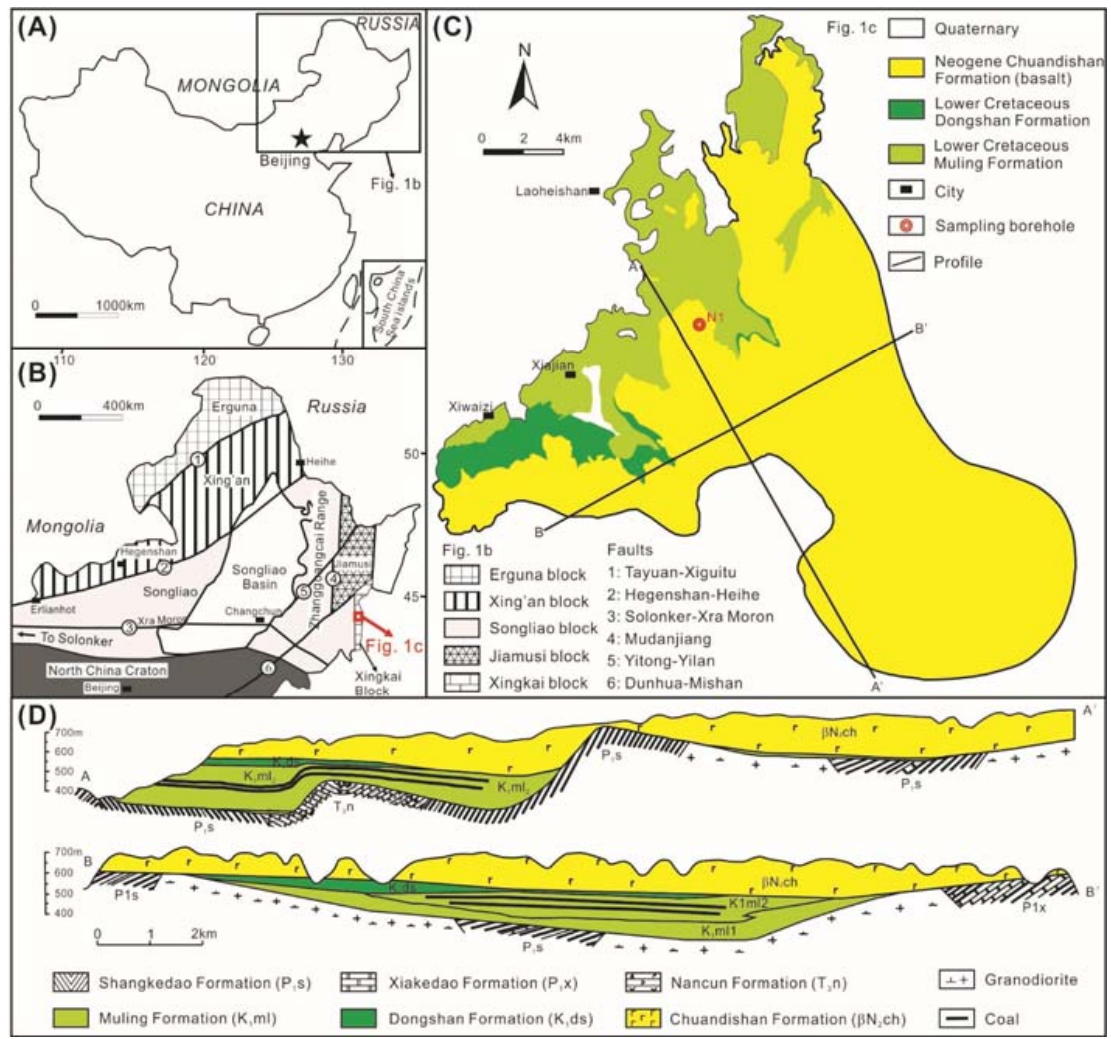

Figure 1. (A) Schematic map of NE China. (B) Simplified geological map of NE China, illustrating the location of the Laoheishan Basin. (C) Geological map of the Laoheishan Basin and the sampling well. (D) Cross profiles of the Laoheishan Basin [28].
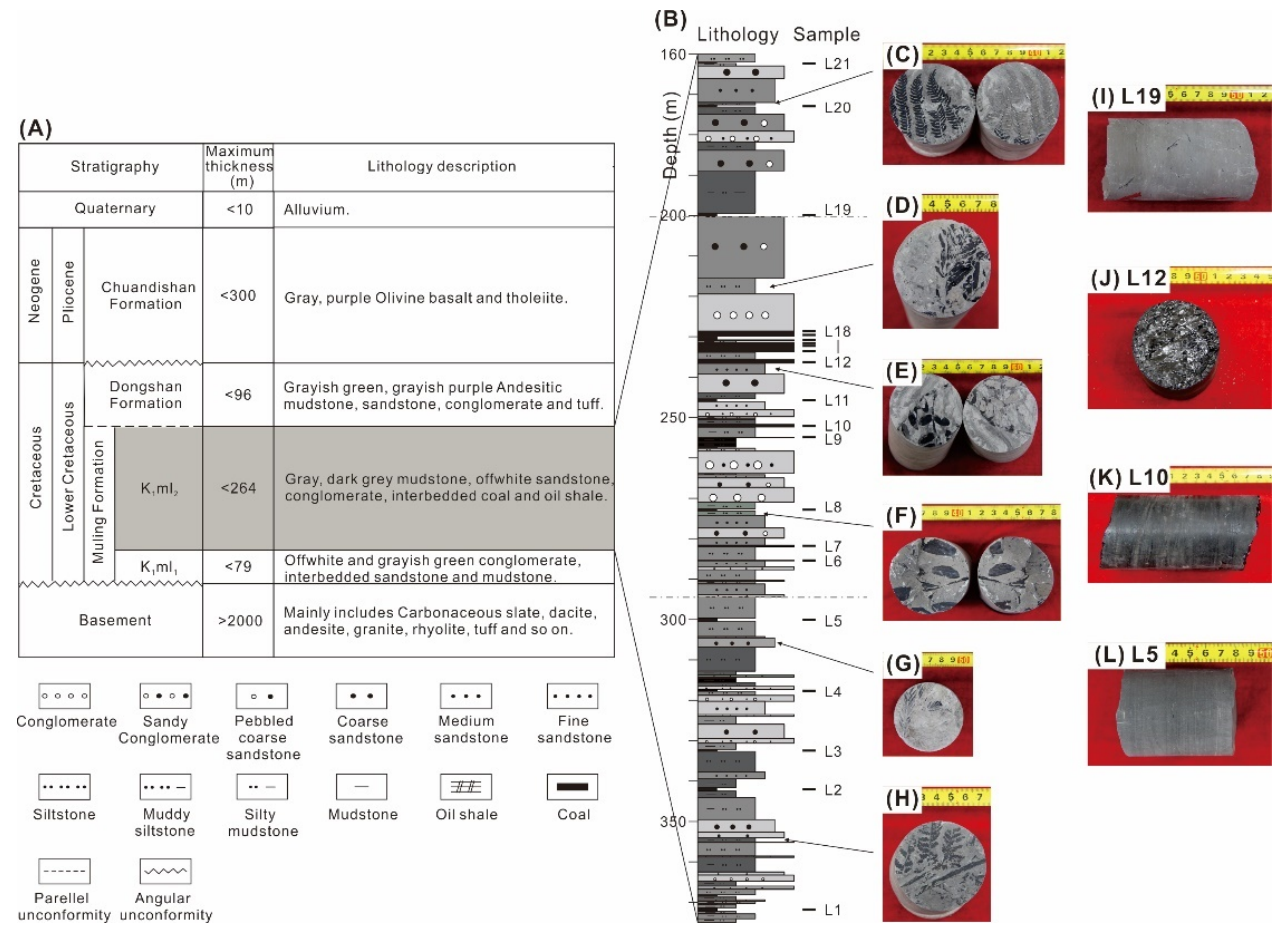

Figure 2. (A) Stratigraphic subdivision of the Laoheishan Basin [28], the studied interval is marked with grey shading. (B) Lithology and sampling depth in the N1. Two horizontal grey lines show the boundaries of three units. Plant fossils observed in the N1: (C,G,H) Ferns. (D-F) Gymnosperms (probably conifers). Macroscopical photos of the studied oil shale $(\mathbf{I}, \mathbf{L})$ and coal $(\mathbf{J}, \mathbf{K})$ samples. 


\section{Samples and Methods}

Twenty-one samples, comprising 10 oil shales and 11 coals, were collected from the Well N1, which is located in the central basin (Figure 1C). The core samples were fresh and the sampling depth is illustrated in Figure 2B. The macroscopical photos of oil shale and coal are provided in Figure 2I-L. All samples were evaluated by ash yield (dry basis; $A_{d}$ ), total organic carbon (TOC), total sulfur (S), Rock-Eval pyrolysis, and maceral biomarker analyses. Two coal samples were selected for vitrinite reflectance (Ro) measurement. Twelve samples, comprising 7 oil shales and 5 coals, were chosen for palynological identification and statistics.

Ash yield was determined following the ASTM Standard D3174-12 [31]. Total organic carbon (TOC) and S contents were analyzed using a Leco CS-230 instrument after pretreatment of samples with $\mathrm{HCl}$, in order to remove carbonate. Pyrolysis was determined using a Rock-Eval 6 instrument. The hydrocarbon generated from kerogen $\left(\mathrm{S}_{2}\right)$ was normalized to TOC to characterize the hydrogen index $\left(\mathrm{HI}=\mathrm{S}_{2} / \mathrm{TOC}^{*} 100\right)$, and the temperature of maximum generation $\left(\mathrm{T}_{\max }\right)$ served as a maturity indicator. These parameters were calculated according to [32]. All of the above analyses were conducted in the Key Laboratory for Oil Shale and Paragenetic Minerals of Jilin Province (Jilin University, Changchun, China).

For palynological investigation, samples were prepared following a standard procedure using $\mathrm{HCl}$ and $\mathrm{HF}$ acids [33]. No oxidative reagents or ultra-sonication were used during the sample preparation. The residues were sieved $(10 \mu \mathrm{m})$ and mounted on slides with polyvinyl alcohol and Canada Balsam. The sections were closely observed using an Olympus BX51 biological microscope with transmitted light. Approximately 200 grains of spores and pollen were counted in each slide to provide the spore-pollen assemblage. The palynological investigation was conducted in the Research Center of Paleontology \& Stratigraphy (Jilin University, China).

Samples for maceral analysis were firstly crushed to a maximum size of $1 \mathrm{~mm}$. The granular samples were then mixed with Canada Balsam and polished for subsequent microscopic observation. A Leica MPV microscope with white and fluorescent lights, equipped with a $50 \times$ objective, was applied. At least 500 points were counted in each slide. The maceral contents refer to volume percentages on a mineral matter-free basis (vol. \%, $\mathrm{mmf}$ ). The Ro of coal samples was determined using a Leica MPV microscope in reflected white light. At least 50 vitrinite (telovitrinite) grains were counted for each slide. Standard materials, including sapphire $(0.59 \%$ reflectance) and gadolinium gallium garnet $(1.72 \%$ reflectance) were used for calibration. Both maceral analysis and Ro measurement were conducted in the Key Laboratory for Oil Shale and Paragenetic Minerals of Jilin Province (Jilin University, China).

Samples for biomarker analysis were firstly extracted by dichloromethane in a Dionex ASE 200 accelerated solvent extractor for about $1 \mathrm{~h}$ to obtain the extractable organic matter (EOM). The EOM was then separated into asphaltenes, NSO compounds, and saturated and aromatic hydrocarbon fractions using centrifugation and medium pressure liquid chromatography (with a Köhnen-Willsch instrument [34]). The saturated and aromatic hydrocarbon fractions were analyzed by a gas chromatograph equipped with a $30 \mathrm{~m} \times 0.25 \mathrm{~mm}$ DB-5MS fused silica column $(0.25 \mu \mathrm{m}$ film thickness $)$ and coupled to a ThermoFisher ISQ quadrupole mass spectrometer (GC-MS). The oven temperature was programmed from $70{ }^{\circ} \mathrm{C}$ to $300{ }^{\circ} \mathrm{C}$ at $4{ }^{\circ} \mathrm{C} / \mathrm{min}$, followed by an isothermal phase of $15 \mathrm{~min}$. Absolute concentrations of compounds in the saturated and aromatic hydrocarbon fractions were calculated in comparison to the peak area of an internal standard (deuterated $n$-tetracosane and 1,1'-binaphthyl for saturated and aromatic fractions, respectively). The concentrations were normalized to the TOC content. The biomarker analysis was completed in the Department of Applied Geosciences and Geophysics (Montanuniversität Leoben, Leoben, Austria). 


\section{Results}

\subsection{Ash Yield and Bulk Geochemistry}

Ash yield (dry basis; $A_{d}$ ) is an important factor for classifying oil shale and coal in the Laoheishan Basin [27]. In this study, the $A_{d}$ values of oil shale range from 45.4 to $61.0 \mathrm{wt}$. \% with an average of $51.8 \mathrm{wt}$. \%, which is higher than those of coal (13.6 to $35.6 \mathrm{wt}$. \%, avg. $25.5 \mathrm{wt}$. \%; Figure 3A). The TOC values of oil shale vary between 5.2 and $21.8 \mathrm{wt}$. \% (avg. 12.8 wt. \%), lower than those of coal (33.1 to 63.7 wt. \%, avg. 48.8 wt. \%; Figure 3B). Most oil shale and coal contain $S$ contents less than $0.5 \mathrm{wt}$. \%; only two coals exhibit $\mathrm{S}$ contents around $1.0 \mathrm{wt}$. \% (Figure $3 \mathrm{C}$ ). The $\mathrm{S}_{2}$ values are characterized by lower values in oil shale $(8.2$ to $79.9 \mathrm{mg} / \mathrm{g}$, avg. $34.1 \mathrm{mg} / \mathrm{g})$ and higher values in coal $(137.7$ to $304.2 \mathrm{mg} / \mathrm{g}$, avg. $202.9 \mathrm{mg} / \mathrm{g}$; Figure 3D). A positive correlation occurred between $\mathrm{S}_{2}$ values and TOC contents in both oil shale and coal $\left(r^{2}=0.86\right.$; Supplementary Figure S1). The HI values range from 140 to $367 \mathrm{mg} / \mathrm{g}$ TOC (avg. $248 \mathrm{mg} / \mathrm{g}$ TOC) and 304 to $589 \mathrm{mg} / \mathrm{g}$ TOC (avg. $417 \mathrm{mg} / \mathrm{g}$ TOC) in oil shale and coal, respectively (Figure 3E), suggesting type II-III kerogen (Supplementary Figure S2). The $\mathrm{T}_{\max }$ values vary between 421 and $429^{\circ} \mathrm{C}$ in oil shale and coal (Figure 3F). Overall, the oil shale characterized by high $A_{d}$, and low values of TOC, $S$, $S_{2}$, and $\mathrm{HI}$, was mainly developed in the lower and upper units, whereas coal with low $A_{d}$ and $\mathrm{S}$ contents, and high values of TOC, $\mathrm{S}_{2}$, and $\mathrm{HI}$, primarily occurred in the middle unit.

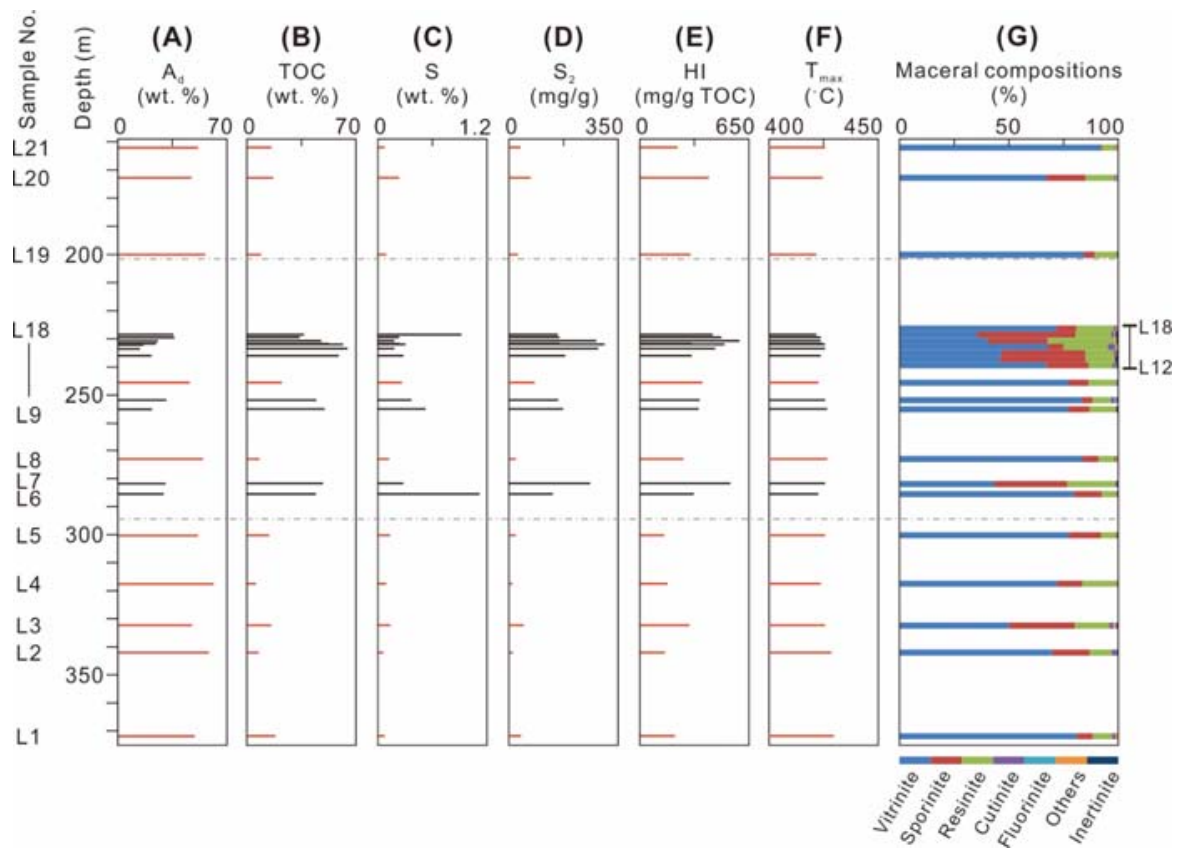

Figure 3. Bulk geochemical parameters of oil shale and coal in the N1. (A) Ash yield, dry basis $\left(A_{d}\right)$. (B) Total organic carbon (TOC). (C) Total sulfur (TS). (D) The hydrocarbons cracked from kerogen during pyrolysis $\left(\mathrm{S}_{2}\right)$. (E) Hydrogen index (HI). (F) The temperature of maximum generation $\left(\mathrm{T}_{\max }\right)$. (G) Maceral compositions; others represent other liptinites, including alginite, suberinite, and liptodetrinite. The red bar represents oil shale and the black bar represents coal. Two horizontal grey lines shows the boundaries of three units.

\subsection{Maceral Composition and Vitrinite Reflectance (Ro)}

Vitrinite was the predominant maceral in oil shale and coal, ranging from 50.2 to 92.0 vol. \% (mmf) and 35.5 to 83.4 vol. \%, respectively (Figure 3G; Supplementary Table S1). Vitrinite was mainly composed of telovitrinite and collodetrinite (Figure 4A,B). No fluorescent was observed in vitrinite under the microscope, indicating the absence of perhydrous vitrinite. Higher percentages of liptinite were observed in coal (19.7-58.8 vol. \%, avg. 39.3 vol. \%) than in oil shale ( $7.8-49.0$ vol. \%, avg. 24.0 vol. \%). Liptinite was dominated by sporinite, resinite, cutinite, and fluorinite, all of which displayed high fluorescence 
under the microscope (Figure 4C-E). Inertinite contents were low in oil shale and coal, with percentages of $<1.5$ vol. \%. Fusinite, including pyrofusinite and degradofusinite, was the commonly observed inertinite, generally revealing high reflectance (Figure 4F). Pyrite was rarely observed in the oil shale and coal, which is consistent with the low sulfur contents $(<1.2 \mathrm{wt}$. \%; Figure 3C). The measured Ro of coal samples was in the range of $0.43-0.44 \%$ (Supplementary Table S1).
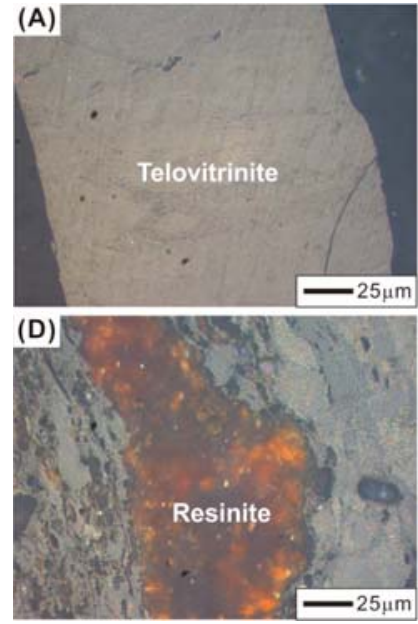
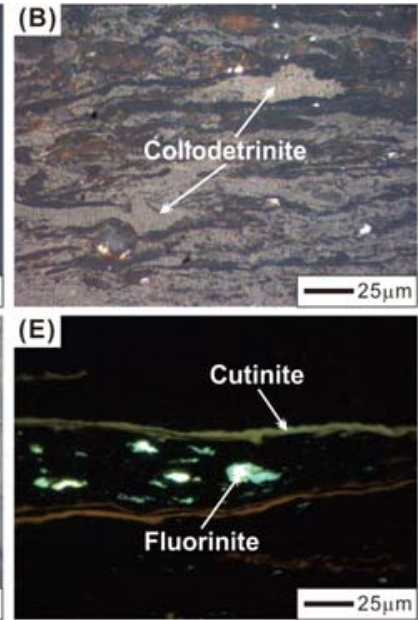
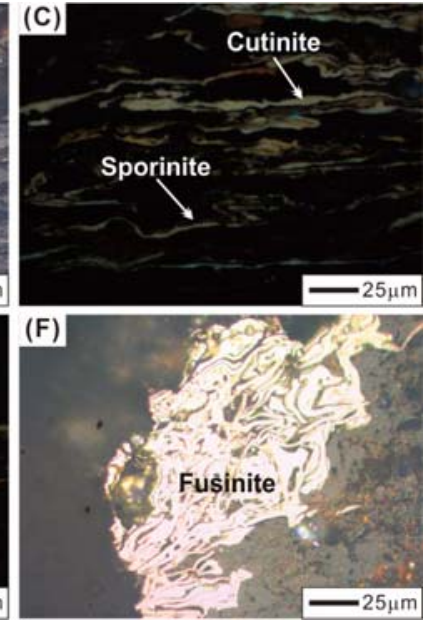

Figure 4. Representative photomicrographs of oil shale and coal (oil immersion). (A) Telovitrinite (incident white light). (B) Collodetrinite (incident white light). (C) The same area of Figure 4B, revealing sporinite and cutinite (blue-light irradiation). (D) Resinite with orange internal reflection (incident white light). (E) Cutinite with fluorinite in between (blue-light irradiation). (F) Pyrofusinite (incident white light).

\subsection{Palynology}

A total of 53 palynomorph taxa (30 spores and 23 pollen taxa) were identified at a species or genus level in oil shale and coal. Selective spores and pollen taxa are shown in Figures 5 and 6, respectively. The preservation of palynomorphs was good, revealing no signs of post depositional degradation [35]. The quantitative distribution patterns of selective spores and pollen are illustrated in Figures 7 and 8, respectively. Distinctive sporepollen assemblages were present in three units. The lower unit was characterized by high spore (avg. 74.1\%) and low pollen (avg. 25.9\%) abundances. The spores were dominated by Concavissimisporites sp. (avg. 18.8\%), Cyathidites sp. (avg. 9.6\%), Cardioangulina sp. (avg. 8.6\%), Pilosisporites sp. (avg. 7.3\%), and Cicatricosisporites purbeckensis (avg. 4.5\%; Figure 7). The middle unit showed significantly lower spore (avg. 35.7\%) and higher pollen (avg. 64.3\%) abundances than the lower unit. Pinuspollenites sp. (avg. 23.4\%), Podocarpidites sp. (avg. 10.7\%), Protoconiferus sp. (avg. 7.0\%), Cedripites sp. (avg. 4.9\%), and Araucariacutes sp. (avg. 4.7\%) were the predominant pollen types (Figure 8). The upper unit consisted of comparable spore (avg. 57.0\%) and pollen (avg. 43.0\%) abundances. The spores mainly comprise Cicatricosisporites sp. (avg. 9.0\%), Osmundacidites sp. (avg. 10.7\%), and Baculatisporites sp. (avg. 8.0\%; Figure 7), whereas the pollen was dominated by Pinuspollenites sp. (avg. 11.1\%) and Podocarpidites sp. (avg. 7.5\%; Figure 8). 

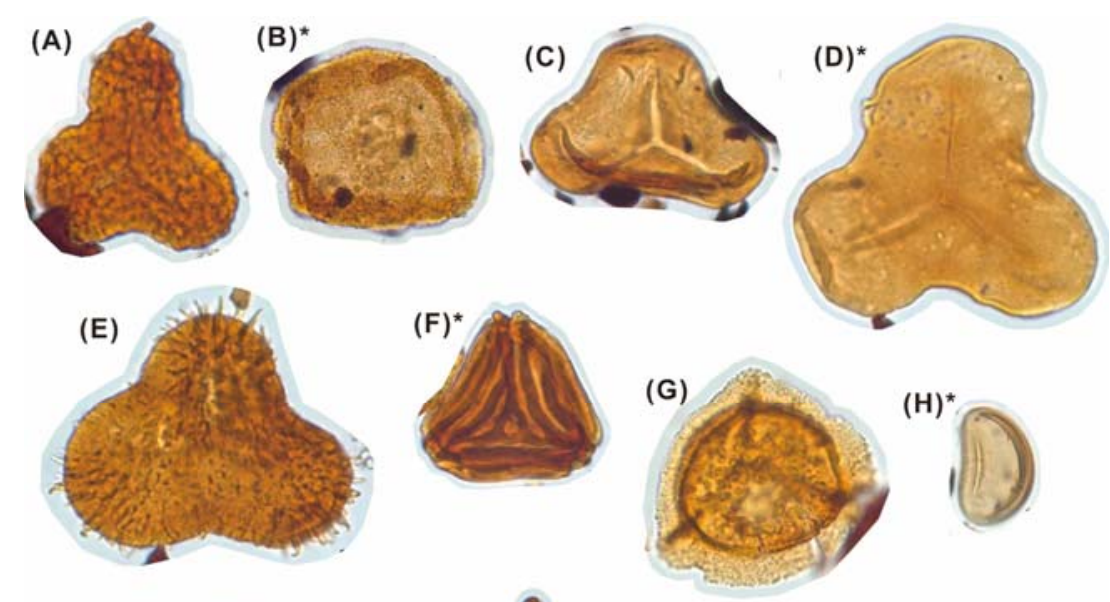

$(\mathrm{H})^{*}$
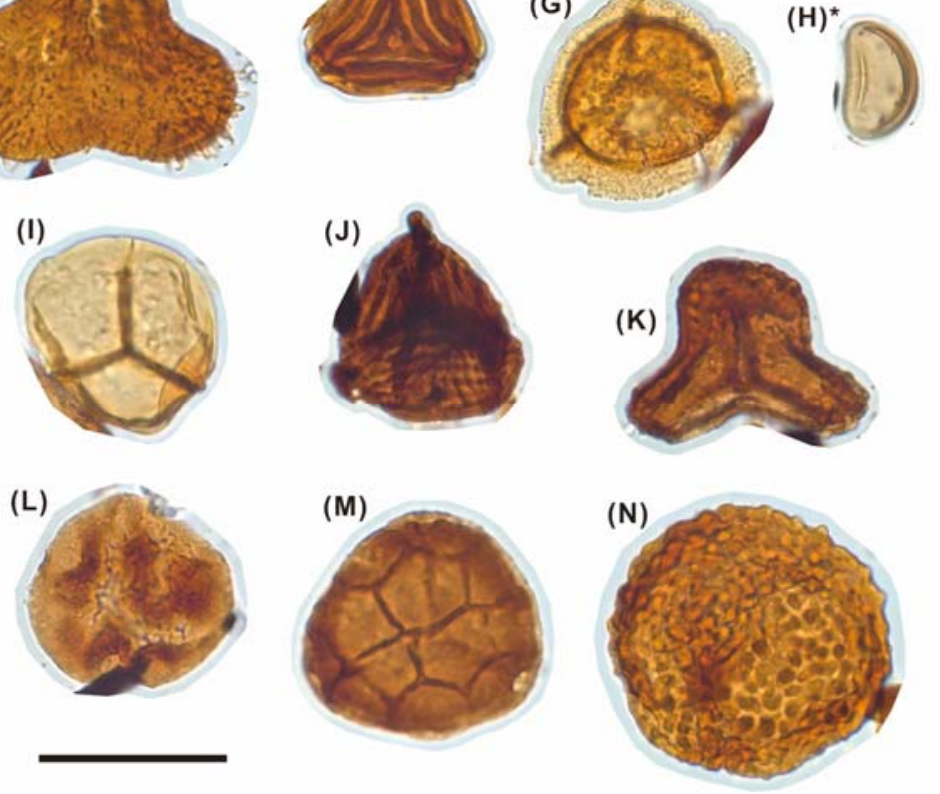

Figure 5. Photomicrographs of spores in oil shale and coal. (A) Concavissimisporites sp. (B) Osmundacidites sp. (C) Cyathidites sp. (D) Cardioangulina sp. (E) Pilosisporites sp. (F) Cicatricosisporites purbeckensis. (G) Aequitriradites sp. (H) Laevigatosporites sp. (I) Biretisporites sp. (J) Appendicisporites sp. (K) Maculatisporites sp. (L) Brochotriletes degradatus. (M) Triporoletes sp. (N) Verrucosisporites sp. The scale bar represents $50 \mu \mathrm{m}$. The photomicrographs marked with * are from [29].

\subsection{Terpenoid Biomarkers}

The biomarker results ( $n$-alkanes, isoprenoids, steroids, hopanoids, and terpenoids) of oil shale and coal from the Laoheishan Basin have been published by Song et al. [5] and elsewhere [27]. In these studies, the terpenoid biomarkers were investigated in detail, to provide evidence for paleovegetational reconstruction; nevertheless, in the recent study we focused on sesquiterpenoids, diterpenoids, and fernanes, which were assigned in the saturated and aromatic fractions in oil shale and coal (Figure 9A,D). Sesquiterpenoids consisted of cadinenes and drimenes in the saturated hydrocarbon fraction (Figure 9B), whereas cuparene, curcumene, 5,6,7,8-tetrahydrocadalene, cadalene, and isocadalene were assigned in the aromatic hydrocarbon fraction (Figure 9E). The saturated diterpenoids comprised ent-beyerane, $16 \mathrm{~b}(\mathrm{H})$-kaurane, and $16 \mathrm{a}(\mathrm{H})$-phyllocladane (Figure $9 \mathrm{C}$ ), whereas simonellite, tetrahydroretene, 19-norabieta-3,8,11,13-tetraene, and retene were the predominant aromatic diterpenoids (Figure 9F). The aromatic compounds with fernane skeleton were assigned, including des-A-ferna-triene, des-A-ferna-tetraene, dinor-ferna-triene, dinorferna-tetraene, and nor-ferna-triene (Figure 9G,H). 


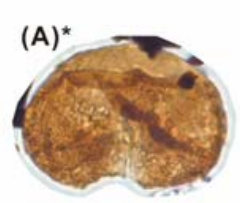

$(B)^{*}$

(D)

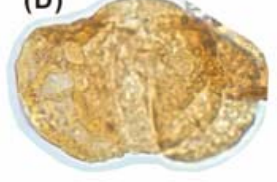

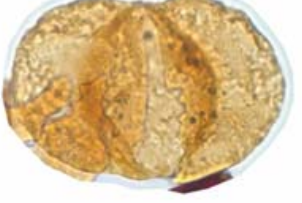

(E).
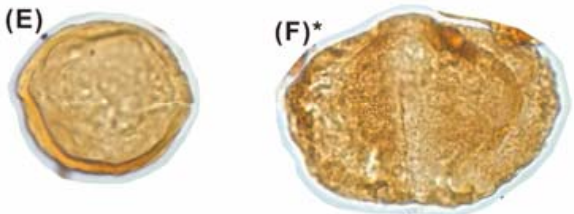
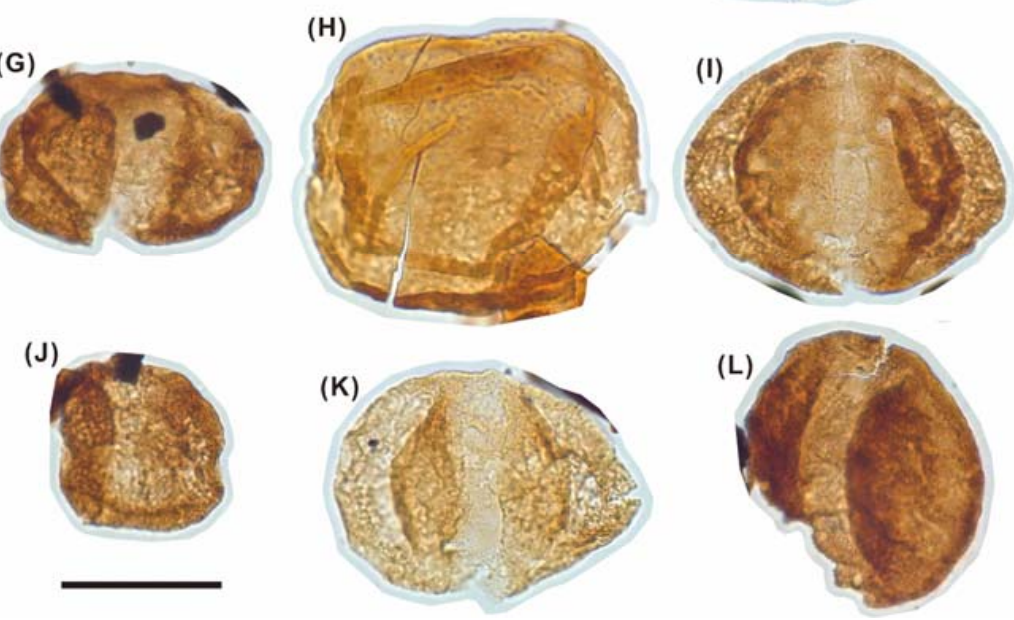

Figure 6. Photomicrographs of selected pollen in oil shale and coal. (A) Pinuspollenites sp. (B) Podocarpidites sp. (C) Protoconiferus sp. (D) Alisporites sp. (E) Araucariacutes sp. (F) Piceites sp. (G) Piceaepollenites sp. (H) Psophosphaera sp. (I) Protopinus sp. (J) Quadraeculina sp. (K) Pseudopicea sp. (L) Pristinuspollenites sp. The scale bar represents $50 \mu \mathrm{m}$. The photomicrographs marked with * are from [29].

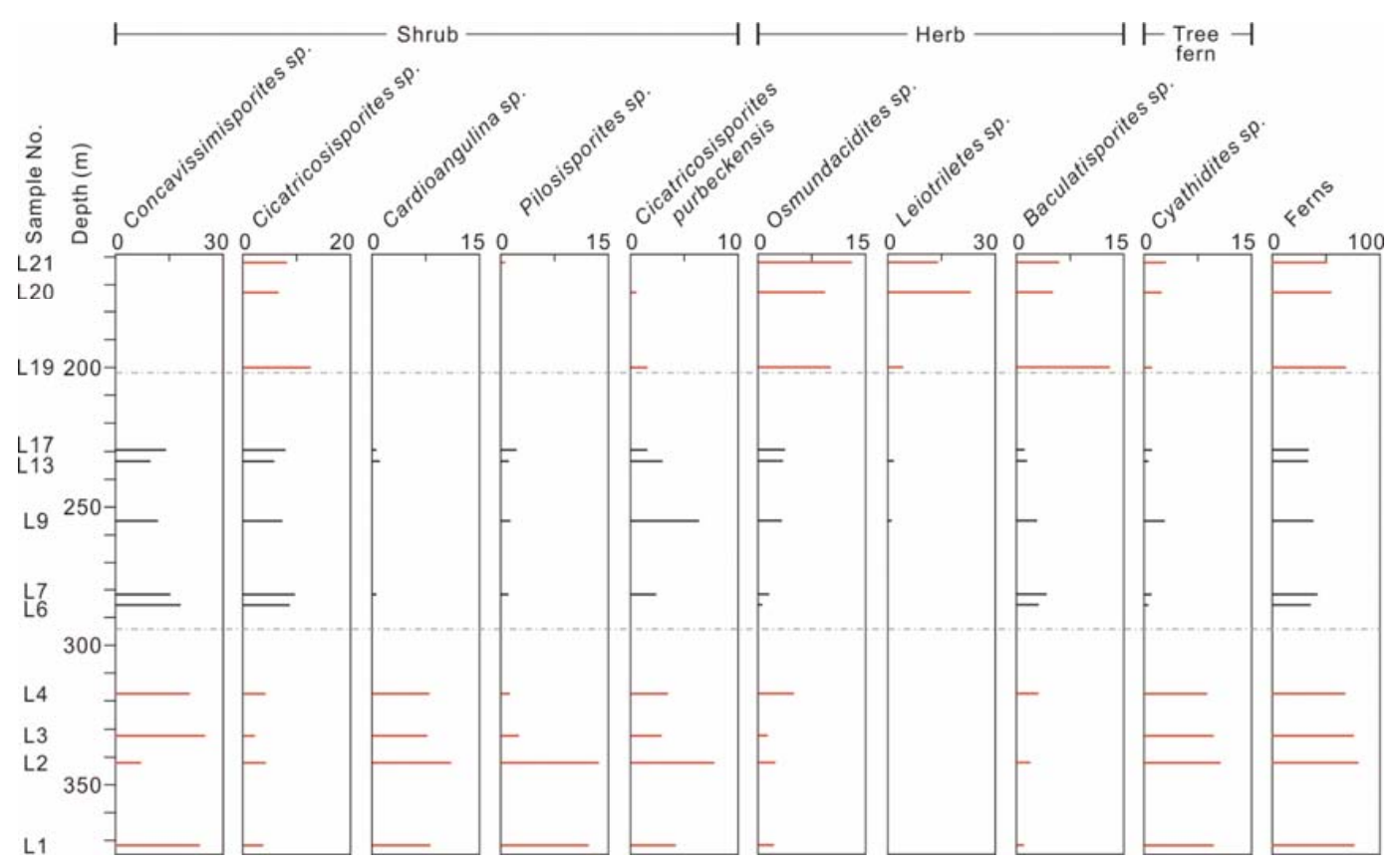

Figure 7. Percentages of major spores in oil shale and coal. The red bar represents oil shale, and the black bar represents coal. The two horizontal grey lines show the boundaries of the three units. 


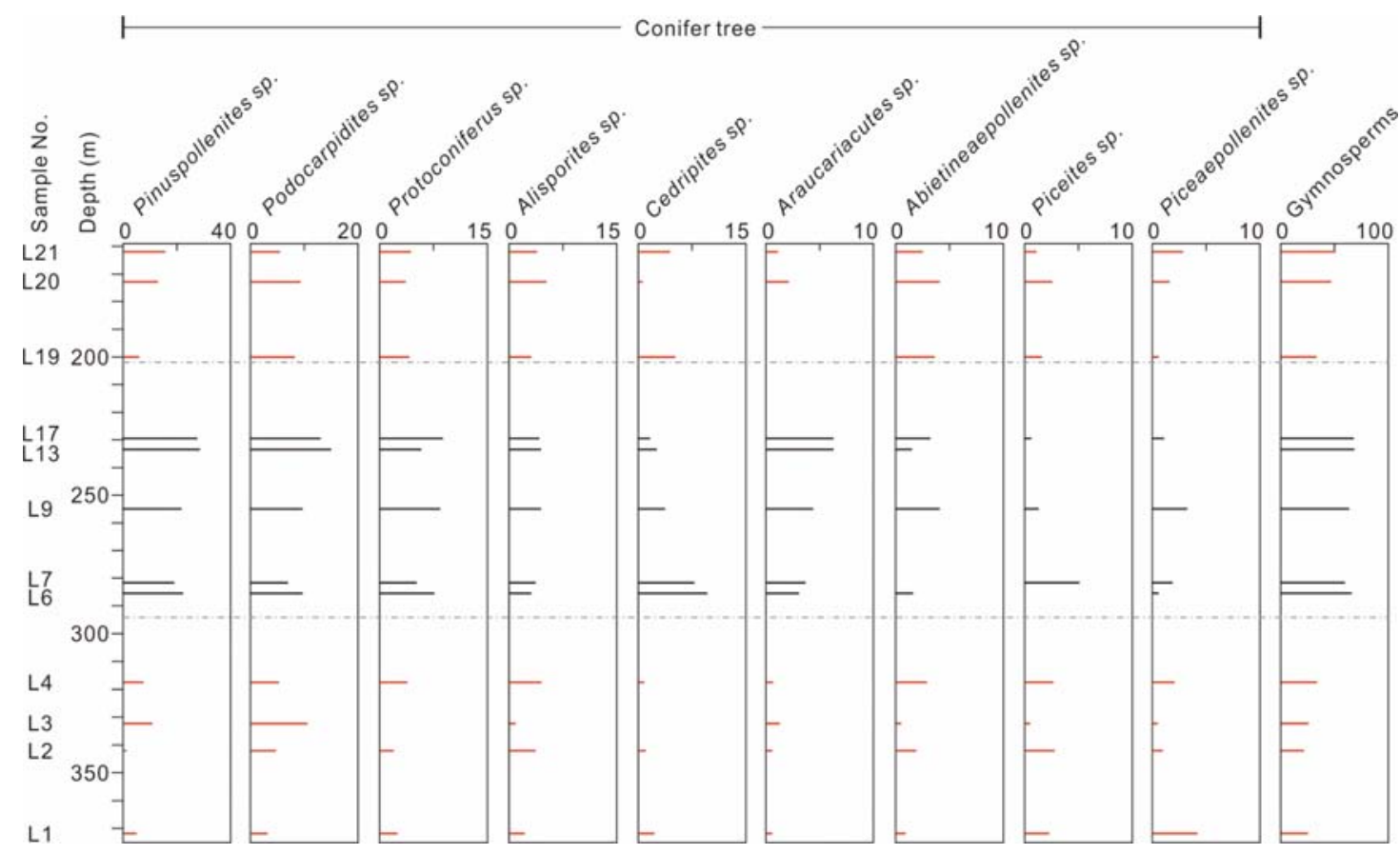

Figure 8. Percentages of major pollen in oil shale and coal. The red bar represents oil shale, and the black bar represents coal. The two horizontal grey lines show the boundaries of the three units.

High concentrations of sesquiterpenoids were observed in the analyzed oil shale and coal, and varied between 62.3 and $272.6 \mu \mathrm{g} / \mathrm{g}$ TOC (avg. $156.9 \mu \mathrm{g} / \mathrm{g}$ TOC; Figure 10), followed by diterpenoids (33.3 to $113.9 \mu \mathrm{g} / \mathrm{g}$ TOC, avg. $74.6 \mu \mathrm{g} / \mathrm{g}$ TOC; Figure 11), and fernanes (5.0 to $51.4 \mu \mathrm{g} / \mathrm{g}$ TOC; avg. $24.4 \mu \mathrm{g} / \mathrm{g}$ TOC; Figure 12). Cadalene was the predominant sesquiterpenoid (avg. $116.4 \mu \mathrm{g} / \mathrm{g}$ TOC), followed by isocadalene (avg. $16.4 \mu \mathrm{g} / \mathrm{g}$ TOC) and tetrahydrocadalene (avg. $10.7 \mu \mathrm{g} / \mathrm{g}$ TOC), whereas others revealed low concentrations (average concentrations $<5.0 \mu \mathrm{g} / \mathrm{g}$ TOC; Figure 10). Diterpenoids were dominated by simonellite (avg. $36.0 \mu \mathrm{g} / \mathrm{g}$ TOC) and retene (avg. $11.4 \mu \mathrm{g} / \mathrm{g}$ TOC), whereas others had average concentrations less than $10 \mu \mathrm{g} / \mathrm{g}$ TOC (Figure 11). Comparable concentrations were observed in five types of fernanes, with average concentrations ranging from $3.8 \mu \mathrm{g} / \mathrm{g}$ TOC (dinor-ferna-tetraene) to $6.5 \mu \mathrm{g} / \mathrm{g}$ TOC (dinor-ferna-triene; Figure 12). In general, the lower and upper units were characterized by low concentrations of sesquiterpenoids and diterpenoids, and high concentrations of fernanes. In contrast, high concentrations of sesquiterpenoids and diterpenoids, together with low concentrations of fernanes, were present in the middle unit. These observations are generally in good agreement with the identified palynoflora from the studied samples. 

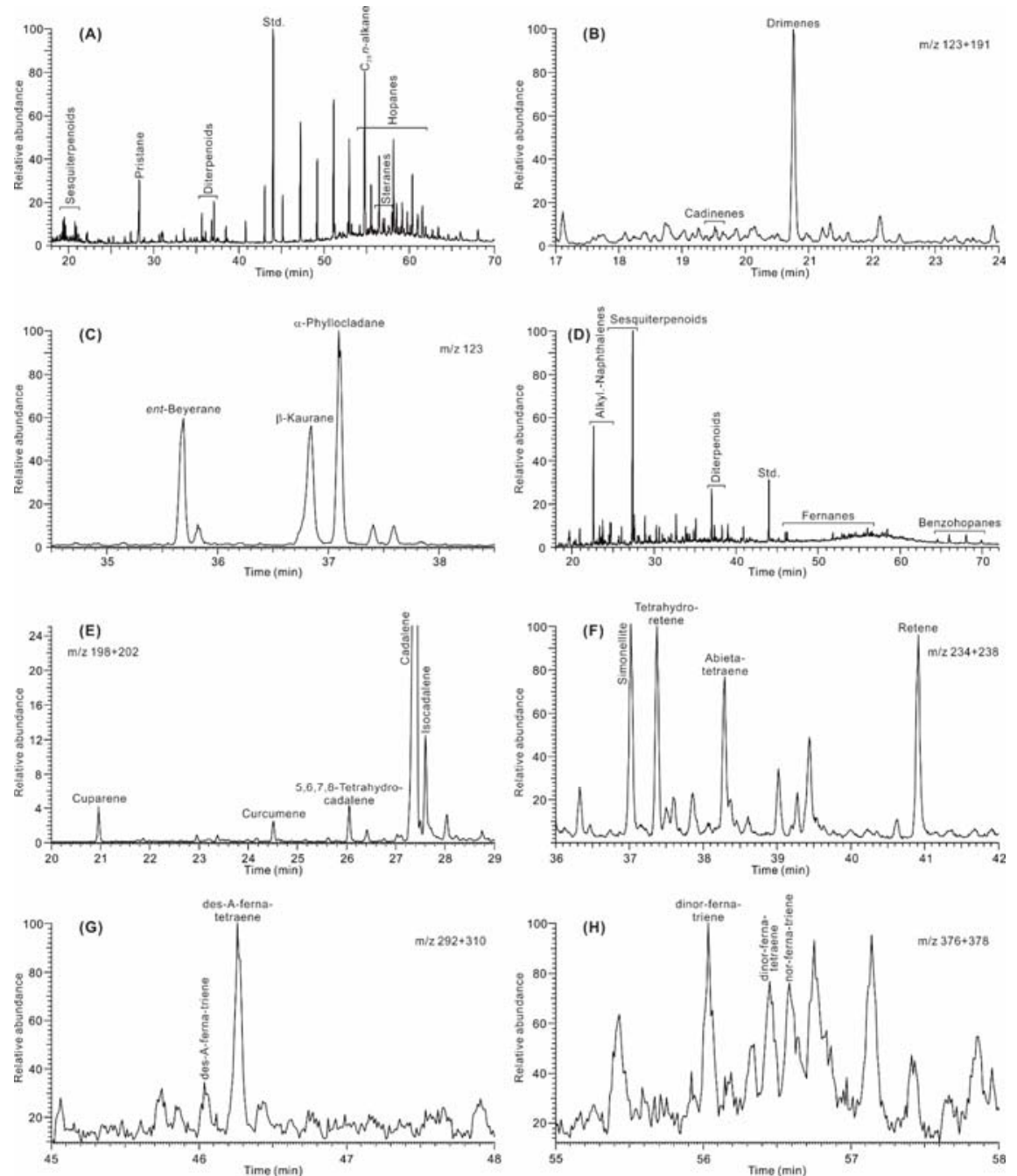

Figure 9. Gas chromatograms and mass chromatograms of a coal sample (L9). (A) Gas chromatogram of saturated hydrocarbon fraction. (B) Mass chromatogram of sesquiterpenoids (saturated hydrocarbon fraction; m/z $123+191$ ). (C) Mass chromatogram of diterpenoids (saturated hydrocarbon fraction; $\mathrm{m} / \mathrm{z}$ 123). (D) Gas chromatogram of aromatic hydrocarbon fraction. (E) Mass chromatogram of sesquiterpenoids (aromatic hydrocarbon fraction; m/z $198+202$ ). (F) Mass chromatogram of diterpenoids (aromatic hydrocarbon fraction; m/z $234+238$ ). (G) Mass chromatogram of fernanes (aromatic hydrocarbon fraction; m/z $292+310$ ). (H) Mass chromatogram of fernanes (aromatic hydrocarbon fraction; m/z $376+378)$. Std., standard. 


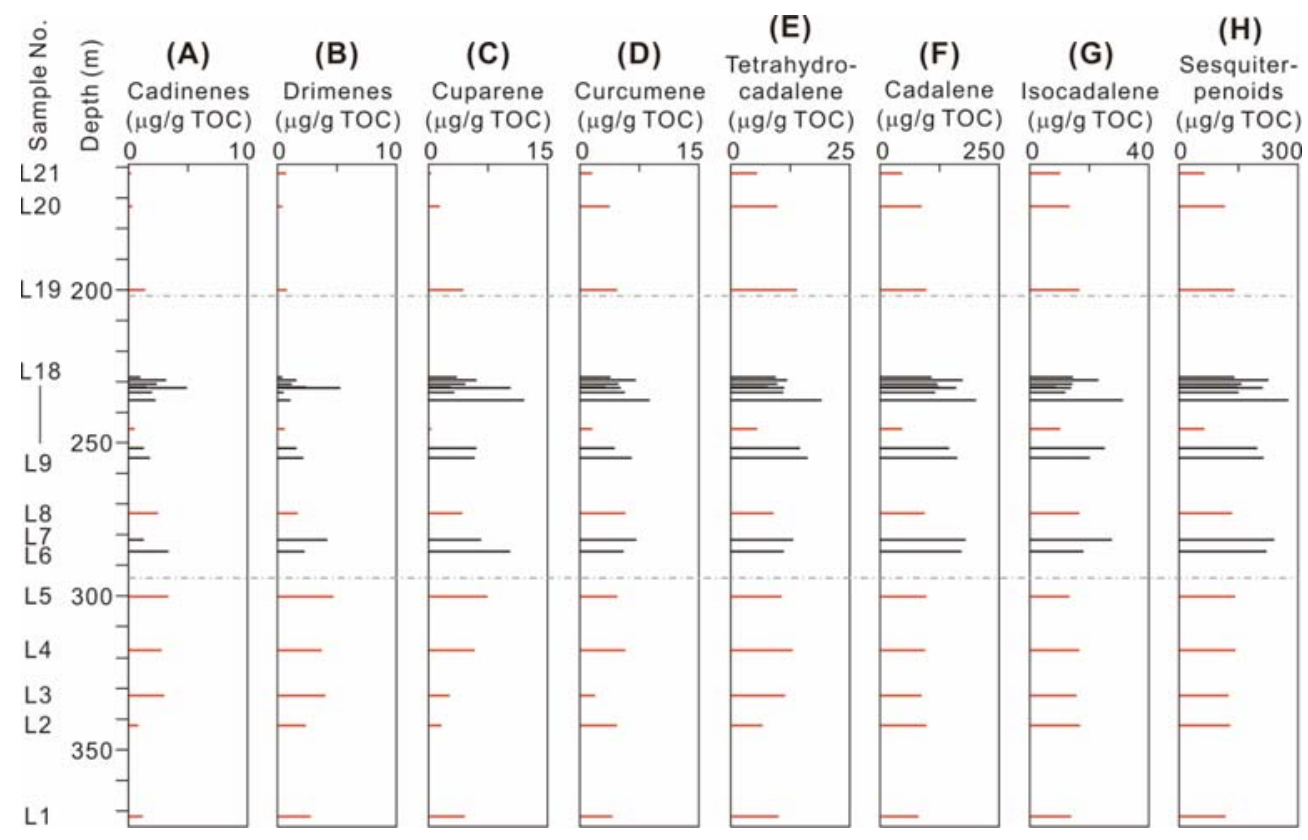

Figure 10. Sesquiterpenoids in saturated and aromatic hydrocarbon fractions of oil shale and coal. (A) Cadinenes. (B) Drimenes. (C) Cuparene. (D) Curcumene. (E) Tetrahydro-cadalene. (F) Cadalene. (G) Isocadalene. (H) Total sesquiterpenoid concentration. The red bar represents oil shale, and the black bar represents coal. The two horizontal grey lines show the boundaries of the three units.

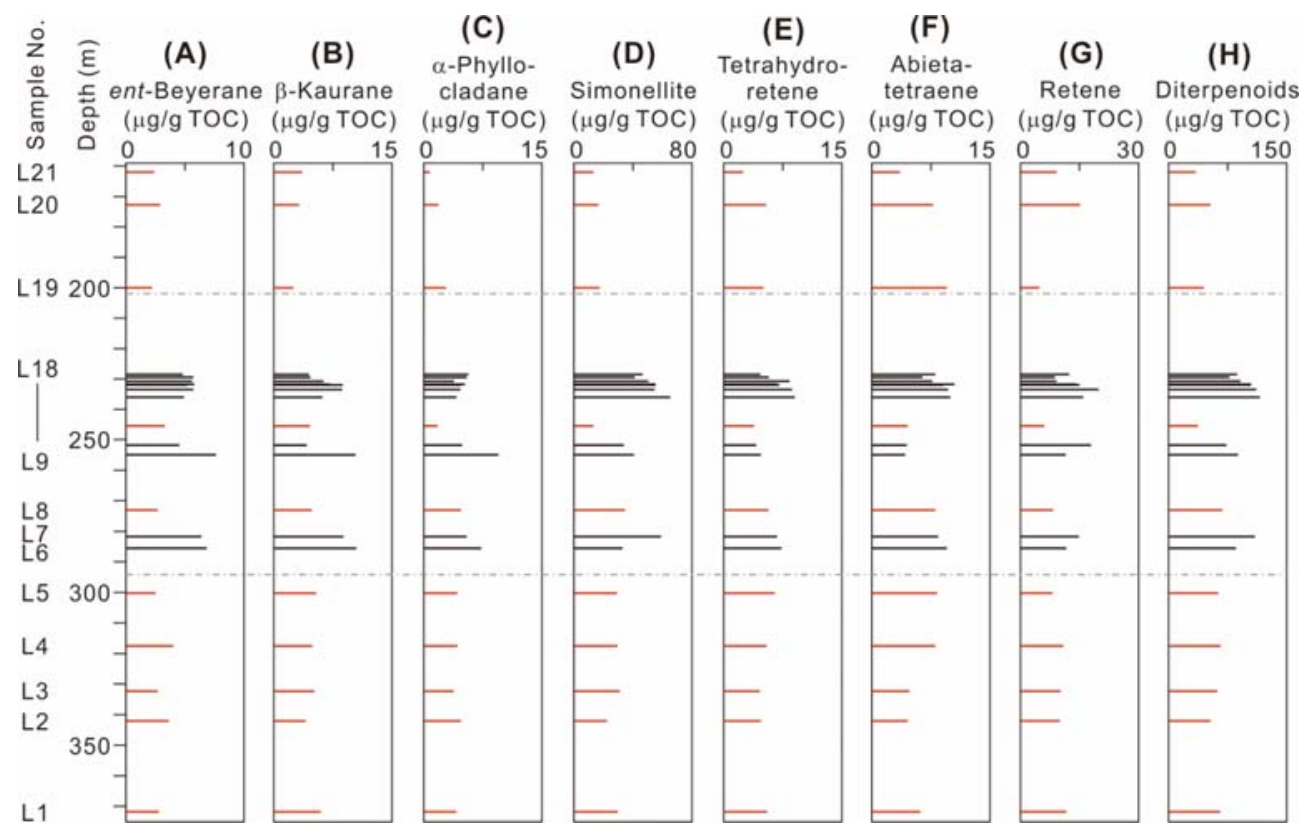

Figure 11. Diterpenoids in saturated and aromatic hydrocarbon fractions of oil shale and coal. (A) ent-Beyerane. (B) b-Kaurane. (C) a-Phyllocladane. (D) Simonellite. (E) Tetrahydro-retene. (F) Abieta-tetraene. (G) Retene. (H) Total diterpenoid concentration. The red bar represents oil shale, and the black bar represents coal. The two horizontal grey lines show the boundaries of the three units. 


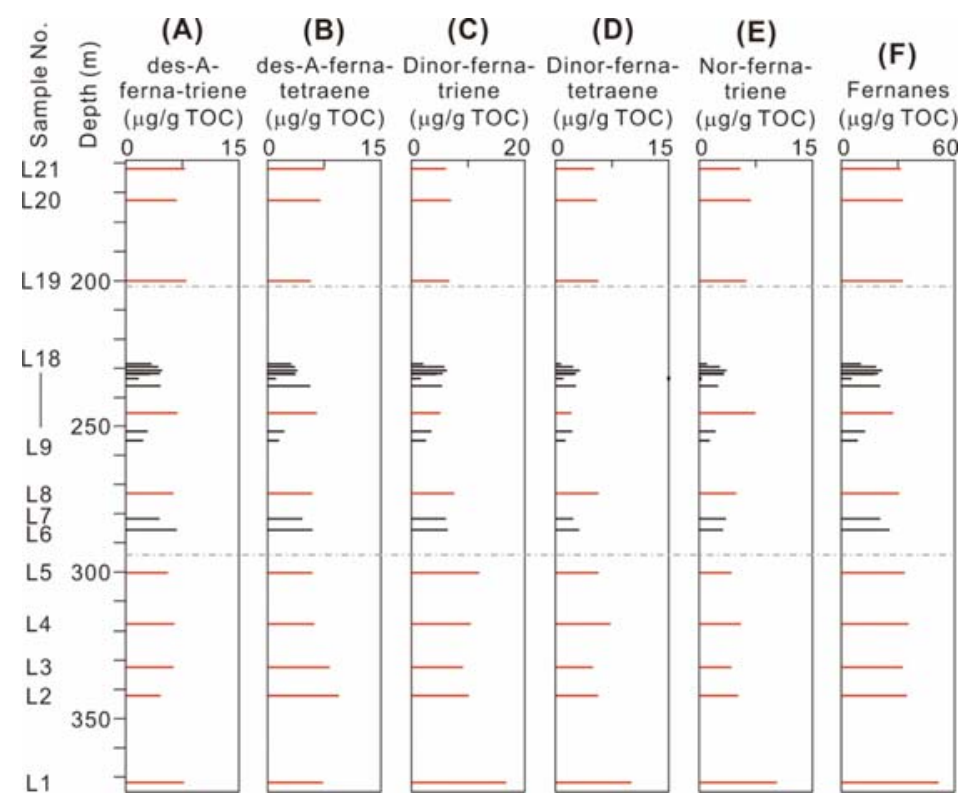

Figure 12. Fernanes in saturated and aromatic hydrocarbon fractions of oil shale and coal. (A) desA-ferna-triene. (B) des-A-ferna-tetraene. (C) Dinor-ferna-triene. (D) Dinor-ferna-tetraene. (E) Norferna-triene. (F) Total fernane concentration. The red bar represents oil shale, and the black bar represents coal. The two horizontal grey lines show the boundaries of the three units.

\section{Discussion}

\subsection{Maturity and Hydrocarbon Generation Potential}

The $T_{\max }$ values of oil shale and coal varied between 421 and $429^{\circ} \mathrm{C}$, revealing an immature character. This interpretation is further supported by the range of measured Ro $(0.43-0.44 \%$; Supplementary Table S1) and the yellow to orange color of the palynomorphs (thermal alteration index 1 to 2; after [36]). According to the modified HI-T max diagram in [37], the studied oil shale sample plots into the area which classified as mixed gas- and oil-prone to gas-prone, whereas the coal samples were classified as oil-prone (Figure 13). This result was further supported by the higher oil yield (determined by Fischer Assay Procedure) in coal (8.2 wt. \% to $14.1 \mathrm{wt}$. \%) than in oil shale (3.6 wt. \% to $7.2 \mathrm{wt}$. \%) from the Laoheishan Basin [27]. Considering the rank-related increase in $\mathrm{HI}$ of low-rank coals, the studied coal samples exceed the minimum HI of $300 \mathrm{mg} / \mathrm{g}$ TOC required for oil generation [38] when their thermal maturity reaches the onset of oil expulsion ("effective $\mathrm{HI}^{\prime \prime}$ in [37]). In addition, because pyrite was rarely observed in the studied oil shale and coal [29], the influence of pyrite on $S_{2}$ during pyrolysis could be excluded. 


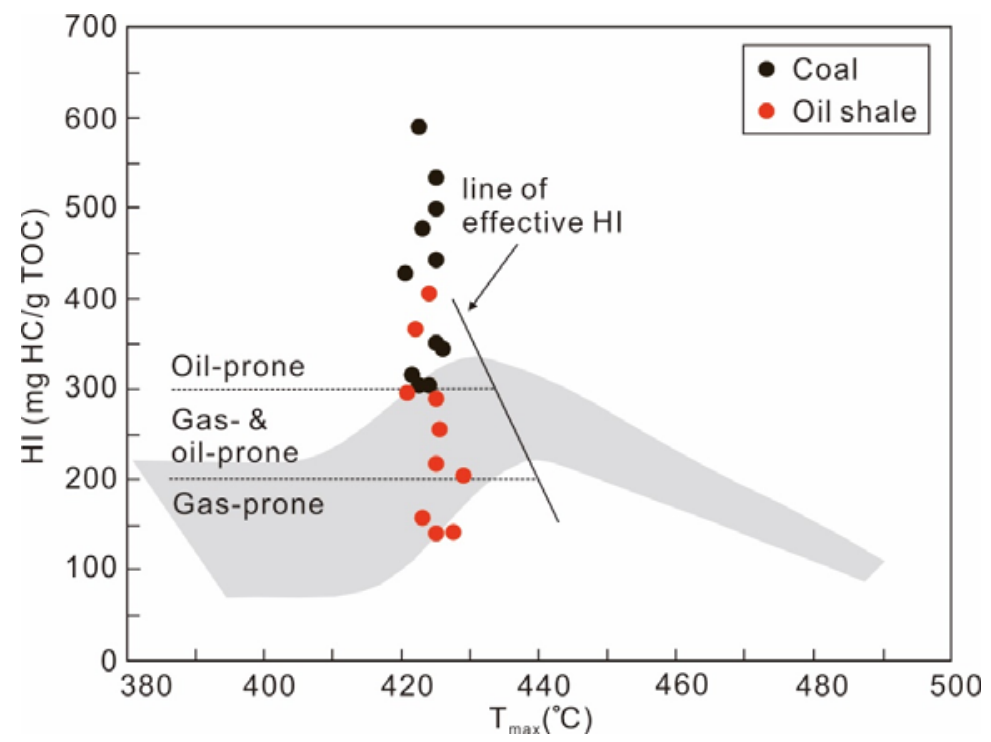

Figure 13. Modified HI- $\mathrm{T}_{\max }$ diagram highlighting the increase in $\mathrm{HI}$ prior to the onset of oil expulsion, after [37]. The classification of kerogen quality is from [39].

\subsection{Paleovegetational Reconstruction}

The palynofloral assemblage of coal-bearing sequences in variable geological ages is an important parameter for paleovegetational reconstruction [35,40-49]. Nevertheless, the sole usage of palynological data could be problematic due to short- and long-distance transportation by surface water and wind, respectively, or positions of the sampled coal seam in the precursor paleomires and/or the quantity of sporomorphs that was produced by mother plants. Therefore, the palynological data should be supported by maceral and biomarker compositions of the studied samples. The palynofloras of the $\mathrm{K}_{1} \mathrm{ml}_{2}$ interval in the Laoheishan Basin comprise palynoflora originating from various plant groups (e.g., ferns and conifers). Information on the botanical affinity, vegetation, and humidity-aridity types of the spores and pollen are provided in Table 1. Six principal groups were recognized based on the compilation, namely, ferns, sphenopsids, bryophytes, lycopods, conifers, and seed ferns. The parent plants can be classified into four vegetation types, i.e., herbs, shrubs, tree ferns, and coniferous trees. In addition, most of the parent plants belong to the humidity-aridity types of phreatophyte and mesophyte, suggesting a humid to semi-humid paleoclimate prevailed during the $\mathrm{K}_{1} \mathrm{ml}_{2}$ interval.

Five typical palynofloral provinces have been classified in China during the early Cretaceous, namely, the Disacciatrileti-Cicatricosisporites Province in the north, the ClassopollisSchizaeoisporites Province in the southeast, the Dicheiropollis Province in the Tibet-Tarim region, the Araucariacites-Callialasporites Province in the southern Tibet, and a wide transitional zone [50]. The northern Disacciatrileti-Cicatricosisporites Province generally contains abundant and diverse bisaccate conifer pollen grains (e.g., Pinaceae and Podocarpaceae) and ferns (especially Cicatricosisporites), whereas Classopollis and Schizaeoisporites are rare [51]. This region has been considered as having a warm-humid paleoclimate during the early Cretaceous [50]. The palynoflora of the $\mathrm{K}_{1} \mathrm{ml}_{2}$ interval in the study area was dominated by highland-related bisaccate coniferous pollen (e.g., Pinuspollenites, Podocarpidites, and Protoconiferus) and fern spores (e.g., Concavissimisporites, Cicatricosisporites, and Osmundacidites), which is similar to the palynoflora of the northern Disacciatrileti-Cicatricosisporites province. 
Table 1. Botanical affinities, vegetation, and humidity-aridity types of principle Early Cretaceous spores and pollen. Representative and comprehensive references include [51-56].

\begin{tabular}{|c|c|c|c|}
\hline Spore-Pollen Taxa or Category & Botanical Affinity & Vegetation Type & Humidity-Aridity Type \\
\hline \multicolumn{4}{|l|}{ Spores } \\
\hline Leiotriletes sp. & Ferns & Herb & Phreatophyte \\
\hline Concavissimisporites sp. & Sphenopsids (Lygodiaceae) & Shrub & Phreatophyte \\
\hline Cicatricosisporites sp. & Ferns (Schizaeaceae) & Shrub & Phreatophyte \\
\hline Osmundacidites sp. & Ferns (Osmundaceae) & Herb & Helophyte \\
\hline Cardioangulina sp. & Sphenopsids (Lygodiaceae) & Shrub & Phreatophyte \\
\hline Cyathidites sp. & Ferns (Dicksoniaceae/Cyatheaceae) & Tree fern & Phreatophyte \\
\hline Baculatisporites sp. & Ferns (Osmundaceae) & Herb & Helophyte \\
\hline Pilosisporites sp. & Ferns & Shrub & Phreatophyte \\
\hline Biretisporites sp. & Ferns (Hymenophyllaceae) & Herb & Helophyte \\
\hline Aequitriradites sp. & Bryophytes & Herb & Phreatophyte \\
\hline Appendicisporites sp. & Ferns (Schizaeaceae) & Shrub & Phreatophyte \\
\hline Toroisporis sp. & Ferns (Marttiaceae) & Herb & Phreatophyte \\
\hline Acanthotriletes sp. & Ferns (Marttiaceae) & Herb & \\
\hline Laevigatosporites sp. & Ferns (Polypodiaceae) & Herb & Helophyte \\
\hline \multicolumn{4}{|l|}{ Maculatisporites sp. } \\
\hline Verrucosisporites sp. & Ferns (Cyatheaceae/Dipteridaceae) & & \\
\hline Neoraistrickia sp. & Lycopods (Pleuromeiaceae/Selaginellaceae) & Herb & Phreatophyte \\
\hline Lycopodiumsporites sp. & Lycopods & Herb & Mesophyte \\
\hline Microreticulatisporites pingyangensis & Ferns & & \\
\hline Converrucosisporites sp. & Ferns (Cyatheaceae/Dipteridaceae) & Herb & Phreatophyte \\
\hline Foveotriletes sp. & Ferns (Cyatheaceae) & Herb & Mesophyte \\
\hline \multicolumn{4}{|l|}{ Brochotriletes degradatus } \\
\hline Cooksonites erenensis & Bryophytes & & \\
\hline Densoisporites sp. & Lycopods (Pleuromeiaceae/Selaginellaceae) & Herb & Phreatophyte \\
\hline \multicolumn{4}{|c|}{ 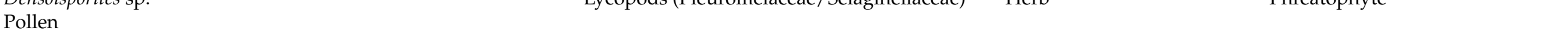 } \\
\hline Pinuspollenites sp. & Conifers (Pinaceae) & Conifer tree & Mesophyte \\
\hline Podocarpidites sp. & Conifers (Podocarpaceae) & Conifer tree & Phreatophyte \\
\hline Alisporites sp. & Seed ferns (Corystospermales) & Conifer tree & \\
\hline Protoconiferus sp. & Conifers (Cupressaceae/Taxodiaceae) & Conifer tree & Phreatophyte \\
\hline Abietineaepollenites sp. & Conifers (Pinaceae) & Conifer tree & Mesophyte \\
\hline Cedripites sp. & Conifers (Pinaceae) & Conifer tree & Mesophyte \\
\hline
\end{tabular}


Table 1. Cont.

\begin{tabular}{|c|c|c|c|}
\hline Spore-Pollen Taxa or Category & Botanical Affinity & Vegetation Type & Humidity-Aridity Type \\
\hline Piceaepollenites sp. & Conifers (Pinaceae) & Conifer tree & Mesophyte \\
\hline Piceites sp. & Conifers (Pinaceae) & Conifer tree & Phreatophyte \\
\hline Psophosphaera sp. & Conifers (Pinaceae) & Conifer tree & Mesophyte \\
\hline Pseudopiceae sp. & Conifers & Conifer tree & Phreatophyte \\
\hline Quadraeculina sp. & Conifers & Conifer tree & \\
\hline Pristinuspollenites sp. & Seed ferns & & \\
\hline Protopinus sp. & Conifers & Conifer tree & Phreatophyte \\
\hline Erlianpollis sp. & Conifers & Conifer tree & Phreatophyte \\
\hline Keteleeria sp. & Conifers (Pinaceae) & Conifer tree & Mesophyte \\
\hline Araucariacutes sp. & Conifers (Araucariaceae) & Conifer tree & Mesophyte \\
\hline Chasmatosporites sp. & Cycadophytes/Ginkgophytes & Shrub & Phreatophyte \\
\hline Concentrisporites fragilis & Conifers (Taxodiaceae) & Conifer tree & \\
\hline Jiaohepollis sp. & Conifers (Araucariaceae) & Conifer tree & Mesophyte \\
\hline Cerebropollenites sp. & Conifers & Conifer tree & \\
\hline \multicolumn{4}{|l|}{ Klausipollenites sp. } \\
\hline Callialasporites sp. & Conifers (Araucariaceae) & Conifer tree & Mesophyte \\
\hline Classopollis sp. & Conifers (Cheirolepidiaceae) & Conifer tree & Xerophyte \\
\hline
\end{tabular}


Based on the identified palynomorph assemblage (Figures 7 and 8), three types of palynofloras were classified into the studied interval, corresponding to three units. In the lower unit interval, the paleovegetation was dominated by shrubs, including Lygodiaceae (Concavissimisporites and Cardioangulina) and Schizaeaceae (Cicatricosisporites), accompanied by tree ferns and coniferous trees, which were represented by Dicksoniaceae/Cyatheaceae (Cyathidites) and Podocarpaceae (Podocarpidites), respectively. The paleovegetation during the middle unit interval was characterized by highland vegetation and peat-forming coniferous plants, including Pinaceae (Pinuspollenites, Cedripites), Araucariaceae (Araucariacutes), Podocarpaceae (Podocarpidites), and Cupressaceae/Taxodiaceae (Protoconiferus). In addition, shrubs also occurred during the middle unit, mainly consisting of Lygodiaceae (Concavissimisporites) and Schizaeaceae (Cicatricosisporites). Different vegetation types, including herbs, shrubs, and coniferous trees, flourished during the upper unit interval. The herbs and shrubs were represented by Osmundaceae (Osmundacidites and Baculatisporites) and Schizaeaceae (Cicatricosisporites), respectively. In addition, the coniferous trees mainly comprised highland vegetation and peat-forming coniferous trees, such as Pinaceae (Pinuspollenites) and Podocarpaceae (Podocarpidites).

The biological precursors of some terpenoids (e.g., cadalene, simonellite, fernanes) are common constituents of tissues from higher plants; therefore, these terpenoids have been widely used to reconstruct the paleovegetation [57-60]. The cadalene-type compounds (cadalene, isocadalene, tetrahydrocadalene) account for more than $90 \%$ of sesquiterpenoids (Figure 10). The cadalene-type sesquiterpenoids have been found in fossil resins of the Pinaceae, Taxodiaceae, Podocarpaceae, Cupressaceae, and Araucariaceae [61], in addition to dammar resins produced by the Dipterocarpaceae (a tropical hardwood, angiosperm [62]). Because angiosperm pollen was not found in the samples, a coniferous trees precursor for the cadalene-type sesquiterpenoids is indicated. Diterpenoids were dominated by the abietane-type compounds (i.e., simonellite and retent; Figure 11; [63]). Abietane-type diterpenoids are proposed as markers for Pinaceae, because of the occurrence of abietic acid in Pinaceae species [57,61]. Nevertheless, these compounds may also be sourced from Pinaceae coniferal detritus or detrital resinite, which could be transported by surface water or wind-blown for short and long distances, respectively $[19,64]$. However, other abietane products, such as phenolic abietane ferruginol, are also widespread in modern species of Podocarpaceae, Cupressaceae, and Taxodiaceae [65,66].

The formation of fernanes is considered to be associated with fernenol, which is widespread in vascular plants, especially ferns $[67,68]$. However, some of the fernane type compounds may also have originated from bacteria, as indicated by the co-occurrence of fern-7-ene and methanogenic biomarkers in modern sediments from an anoxic environment in Antarctica [69,70]. In the present case, there is no doubt that the precursors of fernanes were ferns, because abundant spores were found through the studied interval (Figure 6). As illustrated in Figures 10-12, low concentrations of sesquiterpenoids and diterpenoids, and a high concentration of fernanes, are present in the lower and upper units, probably indicating a paleovegetation dominated by ferns. In contrast, high concentrations of sesquiterpenoids and diterpenoids, together with low concentrations of fernanes, were observed in the middle unit, probably suggesting a paleovegetation characterized by coniferous trees, such as Pinaceae, Podocarpaceae, Cupressaceae, Taxodiaceae, and Araucariaceae. The conclusions are in good agreement with the palynological results.

\subsection{Paleovegetation Influences the Formation of Oil Shale and Coal}

The paleoenvironment and paleovegetation during the formation of oil shale and coal in the Laoheishan Basin are illustrated in Figure 14. Oil shale was deposited in shallow lakes with freshwater, as indicated by low sulfur contents (avg. $0.12 \mathrm{wt}$. \%; Figure 3C). Based on the results of palynology and terpenoid biomarkers, the paleovegetation during the formation of oil shale mainly comprised ferns (e.g., Cicatricosisporites, Osmundacidites, and Cyathidites) and sphenopsids (e.g., Concavissimisporites) on the lake shore, and the high- 
lands in the adjacent regions of the study area hosted coniferous forest (mainly Pinaceae; Figure 14A). Ferns and sphenopsids living on the lake shore may have allowed a large number of spores to enter the lake (transported by surface water and/or wind-blown), and therefore be preserved in the oil shale [52]. In contrast, coal was formed in freshwater low-lying mire, as suggested by high ash yields (avg. $25.5 \mathrm{wt}$. \%) and low sulfur contents (avg. $0.41 \mathrm{wt}$. \%) [71]. The paleovegetation during the formation of coal was composed of highland vegetation and peat-forming coniferous plants, such as Pinaceae, Araucariaceae, Podocarpaceae, Cupressaceae, and Taxodiaceae, accompanied by sphenopsids (e.g., Concavissimisporites) and ferns (e.g., Cicatricosisporites; Figure 14B). Although pollen could be carried a long distance by wind, surface water, and/or insects, a large amount of pollen can still be "in situ" buried due to the flourishing of coniferous trees in the mire (e.g., Podocarpaceae, Cupressaceae, and Taxodiaceae) [72]. In addition, some kinds of coniferous trees, such as Podocarpaceae and Cupressaceae, could produce a large number of resins [73-76]. These resins would be transported into the lake or mire by surface water and/or wind, thus contributing to the formation of hydrogen-rich material (e.g., resinite) in oil shale and coal, and finally resulting in relatively high hydrocarbon generation potential. Because coniferous trees (including highland and peat-forming conifers) flourished in greater numbers in/near the mire than the lake shore (Figure 12), higher hydrocarbon generation potential was commonly present in the coal than in the oil shale. The results reveal the significance of terrestrial organic matter in the formation of excellent (coaly-) source rocks, which has been previously proven by the oil-source correlation results from Southeast Asia, Australia, and Northwest China [77,78].

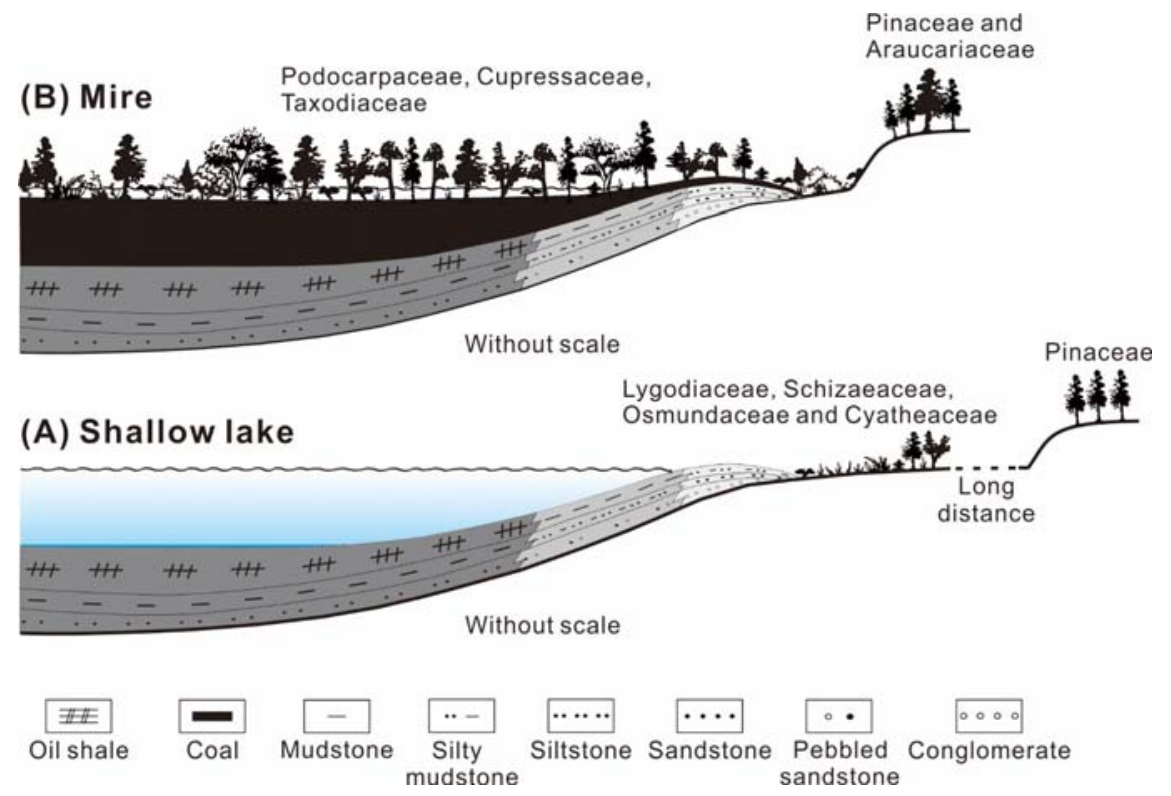

Figure 14. Diagram illustrating the paleoenvironment and paleovegetation during the formation of (A) oil shale and (B) coal.

\section{Conclusions}

Paleovegetational reconstruction and its implications for the formation of oil shale and coal in the Lower Cretaceous Laoheishan Basin were investigated in detail for the first time. Based on the lithological variation, three units were outlined in the studied interval $\left(\mathrm{K}_{1} \mathrm{ml}_{2}\right.$, the upper member of the Lower Cretaceous Muling Formation). Oil shale was mainly developed in the lower and upper units, which were characterized by high $\mathrm{A}_{\mathrm{d}}$ (avg. $51.8 \mathrm{wt.} \%$ ), and low values of TOC (avg. 12.8 wt. \%), S (avg. 0.12 wt. \%), $\mathrm{S}_{2}$ (avg. $34.1 \mathrm{mg} / \mathrm{g}$ ), and HI (avg. $248 \mathrm{mg} / \mathrm{g}$ TOC). In contrast, coal primarily occurred in the middle unit, exhibiting low $\mathrm{A}_{\mathrm{d}}$ (avg. $25.5 \mathrm{wt}$ \%) and $\mathrm{S}$ (avg. $0.41 \mathrm{wt} . \%$ ), and high values of TOC (avg. 48.8 wt. \%), $S_{2}$ (avg. $202.9 \mathrm{mg} / \mathrm{g}$ ), and HI (avg. $417 \mathrm{mg} / \mathrm{g}$ TOC). 
Both oil shale and coal revealed an immature character, as evidenced by the $\mathrm{T}_{\max }$ values $\left(421-429^{\circ} \mathrm{C}\right)$, Ro $(0.43-0.44 \%)$, and yellow to orange color of the palynomorphs (thermal alteration index 1 to 2 ). The palynofloral assemblage and terpenoid biomarker concentrations (sesquiterpenoids, diterpenoids, and fernanes) reflect the existence of various forms of paleovegetation during deposition of the three units. In the lower unit interval, the paleovegetation was represented by shrubs (Lygodiaceae and Schizaeaceae), accompanied by tree ferns (Dicksoniaceae/Cyatheaceae) and coniferous trees (Podocarpaceae). During the formation of the middle unit, the paleovegetation was dominated by highland vegetation and peat-forming coniferous trees, including Pinaceae, Araucariaceae, Podocarpaceae, and Cupressaceae/Taxodiaceae. The paleovegetation in the upper unit interval mainly comprised herbs (Osmundaceae) and shrubs (Schizaeaceae), followed by coniferous trees (Pinaceae and Podocarpaceae). The hydrogen-rich materials (e.g., resin) produced by coniferous trees may be responsible for higher hydrocarbon generation potential in the coal than the oil shale. Overall, our results support the suggestion that the paleovegetation has an influence on the formation of oil shale and coal. In addition, this study provides crucial information for further exploration studies on oil shale and coal in northeast China.

Supplementary Materials: The following are available online at https://www.mdpi.com/article/10 .3390 / en14154704/s1, Figure S1: Cross-plot of total organic carbon (TOC) versus the hydrocarbon generated from kerogen $\left(\mathrm{S}_{2}\right)$ of oil shale and coal samples, Figure S2: Cross-plot of the temperature of maximum generation (Tmax) versus hydrogen index (HI) of oil shale and coal samples, Table S1: Ash yield, bulk geochemistry, maceral composition, and vitrinite reflectance (Ro) of the studied oil shale and coal.

Author Contributions: Conceptualization, Y.S.; Funding acquisition, Y.S. and Y.X.; Investigation, P.S., K.Z. and X.Y.; Methodology, K.Z.; Project administration, Q.M. and Z.L.; Resources, Y.X.; Supervision, Z.L.; Writing—original draft, Y.S. and K.Z.; Writing-review \& editing, Z.L. All authors have read and agreed to the published version of the manuscript.

Funding: We appreciate the thoughtful comments from two anonymous reviewers, and editors Reza Rezaee and Blanca Wang, which significantly improved the quality of the manuscript. We thank Shuqin Zhang (Research Center of Paleontology \& Stratigraphy, Jilin University, China), Eugenia V. Bugdaeva and Valentina S. Markevich (Institute of Biology and Soil Science, Far East Branch, Russian Academy of Sciences, Russia) for their help during the palynological identification. Special thanks to Achim Bechtel for his help during the biomarker analysis in Austria. This study was supported by National Science Foundation of China (Grant No. 41902139).

Conflicts of Interest: The authors declare no conflict of interest.

\section{References}

1. Strobl, S.A.I.; Sachsenhofer, R.F.; Bechtel, A.; Meng, Q.; Sun, P. Deposition of coal and oil shale in NE China: The Eocene Huadian Basin compared to the coeval Fushun Basin. Mar. Pet. Geol. 2015, 64, 347-362. [CrossRef]

2. Sun, P.; Sachsenhofer, R.F.; Liu, Z.; Strobl, S.A.I.; Meng, Q.; Liu, R.; Zhen, Z. Organic matter accumulation in the oil shale- and coal-bearing Huadian Basin (Eocene; NE China). Int. J. Coal Geol. 2013, 105, 1-15. [CrossRef]

3. Bai, Y.; Liu, Z.; Sun, P.; Liu, R.; Hu, X.; Zhou, R.; Xu, Y.; Zhao, H.; Wang, J. Diverse sedimentary conditions during deposition of coal and oil shale from the Meihe Basin (Eocene, NE China). J. Sediment. Res. 2017, 87, 1100-1120. [CrossRef]

4. Lv, D.; Wang, D.; Li, Z.; Liu, H.; Li, Y. Depositional environment, sequence stratigraphy and sedimentary mineralization mechanism in the coal bed- and oil shale-bearing succession: A case from the Paleogene Huangxian Basin of China. J. Pet. Sci. Eng. 2017, 148, 32-51. [CrossRef]

5. Song, Y.; Liu, Z.; Bechtel, A.; Sachsenhofer, R.F.; Groß, D.; Meng, Q. Paleoenvironmental reconstruction of the coal- and oil shale-bearing interval in the lower Cretaceous Muling Formation, Laoheishan Basin, northeast China. Int. J. Coal Geol. 2017, 172, 1-18. [CrossRef]

6. Wang, J.; Sun, P.; Liu, Z.; Li, Y. Characteristics and genesis of lacustrine laminar coal and oil shale: A case study in the Dachanggou Basin, Xinjiang, Northwest China. Mar. Pet. Geol. 2021, 126, 104924. [CrossRef]

7. Gibling, M.R.; Ukakimaphan, Y.; Srisuk, S. Oil Shale and Coal in Intermontane Basins of Thailand. AAPG Bull. 1985, 69, 760-766.

8. Wolela, A. Fossil fuel energy resources of Ethiopia: Oil shale deposits. J. Afr. Earth Sci. 2006, 46, 263-280. [CrossRef]

9. Cameron, A.R.; Goodarzi, F.; Potter, J. Coal and oil shale of Early Carboniferous age in northern Canada: Significance for paleoenvironmental and paleoclimatic interpretations. Palaeogeogr. Palaeoclimatol. Palaeoecol. 1994, 106, 135-155. [CrossRef] 
10. Şener, M.; Şengüler, I.; Kök, M.V. Geological considerations for the economic evaluation of oil shale deposits in Turkey. Fuel 1995, 74, 999-1003. [CrossRef]

11. Kara-Gülbay, R.; Korkmaz, S. Element contents and organic matter-element relationship of the Tertiary oil shale deposits in northwest Anatolia, Turkey. Energy Fuels 2008, 22, 3164-3173. [CrossRef]

12. Bechtel, A.; Karayiğit, A.I.; Sachsenhofer, R.F.; Inaner, H.; Christanis, K.; Gratzer, R. Spatial and temporal variability in vegetation and coal facies as reflected by organic petrological and geochemical data in the Middle Miocene Çayirhan coal field (Turkey). Int. J. Coal Geol. 2014, 134-135, 46-60. [CrossRef]

13. Wang, S.; Jiang, X.; Han, X.; Tong, J. Investigation of Chinese oil shale resources comprehensive utilization performance. Energy 2012, 42, 224-232. [CrossRef]

14. Miao, Z.; Wu, G.; Li, P.; Meng, X.; Zheng, Z. Investigation into co-pyrolysis characteristics of oil shale and coal. Int. J. Min. Sci. Technol. 2012, 22, 245-249. [CrossRef]

15. Meng, Q.; Bruch, A.A.; Sun, G.; Liu, Z.; Hu, F.; Sun, P. Quantitative reconstruction of Middle and Late Eocene paleoclimate based on palynological records from the Huadian Basin, northeastern China: Evidence for monsoonal influence on oil shale formation. Palaeogeogr. Palaeoclimatol. Palaeoecol. 2018, 510, 63-77. [CrossRef]

16. Jia, J.; Liu, Z.; Bechtel, A.; Strobl, S.A.I.; Sun, P. Tectonic and climate control of oil shale deposition in the Upper Cretaceous Qingshankou Formation (Songliao Basin, NE China). Int. J. Earth Sci. 2013, 102, 1717-1734. [CrossRef]

17. Liu, B.; Song, Y.; Zhu, K.; Su, P.; Ye, X.; Zhao, W. Mineralogy and element geochemistry of salinized lacustrine organic-rich shale in the Middle Permian Santanghu Basin: Implications for paleoenvironment, provenance, tectonic setting and shale oil potential. Mar. Pet. Geol. 2020, 120, 104569. [CrossRef]

18. Xu, J.; Liu, Z.; Bechtel, A.; Sachsenhofer, R.F.; Jia, J.; Meng, Q.; Sun, P. Organic matter accumulation in the Upper Cretaceous Qingshankou and Nenjiang Formations, Songliao Basin (NE China): Implications from high- resolution geochemical analysis. Mar. Pet. Geol. 2019, 102, 187-201. [CrossRef]

19. Oskay, R.G.; Bechtel, A.; Karayiğit, A.İ. Mineralogy, petrography and organic geochemistry of Miocene coal seams in the Kınık coalfield (Soma Basin-Western Turkey): Insights into depositional environment and palaeovegetation. Int. J. Coal Geol. 2019, 210, 103205. [CrossRef]

20. Tao, S.; Xu, Y.; Tang, D.; Xu, H.; Li, S.; Chen, S.; Liu, W.; Cui, Y.; Gou, M. Geochemistry of the Shitoumei oil shale in the Santanghu Basin, Northwest China: Implications for paleoclimate conditions, weathering, provenance and tectonic setting. Int. J. Coal Geol. 2017, 184, 42-56. [CrossRef]

21. Zhao, Z.; Littke, R.; Zieger, L.; Hou, D.; Froidl, F. Depositional environment, thermal maturity and shale oil potential of the Cretaceous Qingshankou Formation in the eastern Changling Sag, Songliao Basin, China: An integrated organic and inorganic geochemistry approach. Int. J. Coal Geol. 2020, 232, 103621. [CrossRef]

22. Zhang, P.; Meng, Q.; Misch, D.; Sachsenhofer, R.F.; Liu, Z.; Hu, F.; Shen, L. Oil shale potential of the lower cretaceous Jiufotang Formation, Beipiao Basin, Northeast China. Int. J. Coal Geol. 2021, 236, 103640. [CrossRef]

23. Dyni, J.R. Geology and resources of some world oil shale deposits. Oil Shale 2003, 20, 193-252.

24. Liu, Z.; Yang, H.; Dong, Q.; Zhu, J.; Guo, W. Oil Shale in China; Petroleum Industry Press: Beijing, China, 2009 ; pp. 14-115.

25. Liu, Z.; Meng, Q.; Dong, Q.; Zhu, J.; Guo, W.; Ye, S.; Liu, R.; Jia, J. Characteristics and Resource Potential of Oil Shale in China. Oil Shale 2017, 34, 15-41. [CrossRef]

26. Liu, R.; Liu, Z.; Liu, S.; Liu, D.; Li, B.; Yang, X.; Xu, Y. Coal and oil shale occurrence characteristic and metallogenic regularity in Yilan Basin. J. China Coal Soc. 2012, 37, 776-781.

27. Song, Y.; Bechtel, A.; Sachsenhofer, R.F.; Groß, D.; Liu, Z.; Meng, Q. Depositional environment of the Lower Cretaceous Muling Formation of the Laoheishan Basin (NE China): Implications from geochemical and petrological analyses. Org. Geochem. 2017, 104, 19-34. [CrossRef]

28. Song, Y.; Liu, Z.; Meng, Q.; Wang, Y.; Zheng, G.; Xu, Y. Petrography and geochemistry characteristics of the lower Cretaceous Muling Formation from the Laoheishan Basin, Northeast China: Implications for provenance and tectonic setting. Mineral. Petrol. 2017, 111, 383-397. [CrossRef]

29. Song, Y.; Liu, Z.; Groß, D.; Meng, Q.; Xu, Y. Petrology, mineralogy and geochemistry of the Lower Cretaceous oil-prone coal and host rocks from the Laoheishan Basin, northeast China. Int. J. Coal Geol. 2018, 191, 7-23. [CrossRef]

30. Xu, W.; Wang, F.; Meng, E.; Gao, F.; Pei, F.; Yu, J.; Tang, J. Paleozoic-early Mesozoic tectonic evolution in the eastern Heilongjiang province, NE China: Evidence from igneous rock association and U-Pb geochronology of detrital zircons. J. Jilin Univ. (Earth Sci. Ed.) 2012, 42, 1378-1389.

31. ASTM International. ASTM Standard D3174-12. In Test Method for Ash in the Analysis Sample of Coal and Coke from Coal; ASTM International: West Conshohocken, PA, USA, 2012.

32. Lafargue, E.; Marquis, F.; Pillot, D. Rock-Eval 6 applications in hydrocarbon exploration, production, and soil contamination studies. Rev. Inst. Fr. Pét. 1998, 53, 421-437. [CrossRef]

33. Traverse, A. Paleopalynology; Springer: Dordrecht, The Netherlands, 2007; p. 813.

34. Radke, M.; Willsch, H.; Welte, D.H. Preparative hydrocarbon group type determination by automated medium pressure liquid chromatography. Anal. Chem. 1980, 52, 406-411. [CrossRef]

35. Schneider, A.C.; Heimhofer, U.; Heunisch, C.; Mutterlose, J. From arid to humid-The Jurassic-Cretaceous boundary interval in northern Germany. Rev. Palaeobot. Palynol. 2018, 255, 57-69. [CrossRef] 
36. Staplin, F.L. Sedimentary organic matter, organic metamorphism and oil and gas occurrence. Bull. Can. Petrol. Geol. 1969, 17, 47-66.

37. Sykes, R.; Snowdon, L.R. Guidelines for assessing the petroleum potential of coaly source rocks using Rock-Eval pyrolysis. Org. Geochem. 2002, 33, 1441-1455. [CrossRef]

38. Pepper, A.S.; Corvi, P.J. Simple kinetic models of petroleum formation. Part III: Modeling an open system. Mar. Pet. Geol. 1995, 12, 417-452. [CrossRef]

39. Peters, K.E.; Moldowan, J.M. The Biomarker Guide: Interpreting Molecular Fossils in Petroleum and Ancient Sediments; Prentice Hall: Englewood Cliffs, NJ, USA, 1993; pp. 550-590.

40. Wang, Y.; Mosbrugger, V.; Zhang, H. Early to Middle Jurassic vegetation and climatic events in the Qaidam Basin, Northwest China. Palaeogeogr. Palaeoclimatol. Palaeoecol. 2005, 224, 200-216. [CrossRef]

41. Petersen, H.I.; Lindström, S.; Therkelsen, J.; Pedersen, G.K. Deposition, floral composition and sequence stratigraphy of uppermost Triassic (Rhaetian) coastal coals, southern Sweden. Int. J. Coal Geol. 2013, 116-117, 117-134. [CrossRef]

42. Eble, C.F. Palynology of late Middle Pennsylvanian coal beds in the Appalachian Basin. Int. J. Coal Geol. 2002, 50, 73-88. [CrossRef]

43. Hower, J.C.; Ruppert, L.F.; Eble, C.F.; Clark, W.L. Geochemistry, petrology, and palynology of the Pond Creek coal bed, northern Pike and southern Martin counties, Kentucky. Int. J. Coal Geol. 2005, 62, 167-181. [CrossRef]

44. Çelik, Y.; Karayiğit, A.İ; Querol, X.; Oskay, R.G.; Mastalerz, M.; Kayseri Özer, M.S. Coal characteristics, palynology, and palaeoenvironmental interpretation of the Yeniköy coal of Late Oligocene age in the Thrace Basin (NW Turkey). Int. J. Coal Geol. 2017, 181, 103-123. [CrossRef]

45. Çelik, Y.; Karayigit, A.I.; Oskay, R.G.; Kayseri-Özer, M.S.; Christanis, K.; Hower, J.C.; Querol, X. A multidisciplinary study and palaeoenvironmental interpretation of middle Miocene Keles lignite (Harmanckk Basin, NW Turkey), with emphasis on syngenetic zeolite formation. Int. J. Coal Geol. 2021, 237, 103691. [CrossRef]

46. Johnston, M.N.; Eble, C.F.; O'Keefe, J.M.K.; Freeman, R.L.; Hower, J.C. Petrology and palynology of the Middle Pennsylvanian Leatherwood coal bed, Eastern Kentucky: Indications for depositional environments. Int. J. Coal Geol. 2017, 181, 23-38. [CrossRef]

47. Mishra, S.; Singh, V.P. Palynology, palynofacies, and taphonomical studies of Kamthi Formation, (Godavari Graben), southern India: Implications to biostratigraphy, palaeoecology, and depositional environment. Int. J. Coal Geol. 2018, 195, 102-124. [CrossRef]

48. Eble, C.F.; Greb, S.F.; Williams, D.A.; Hower, J.C.; O’Keefe, J.M.K. Palynology, organic petrology and geochemistry of the Bell coal bed in Western Kentucky, Eastern Interior (Illinois) Basin, USA. Int. J. Coal Geol. 2019, 213, 103264. [CrossRef]

49. Wagner, N.; Eble, C.; Hower, J.; Falcon, R. Petrology and palynology of select coal samples from the Permian Waterberg Coalfield, South Africa. Int. J. Coal Geol. 2019, 204, 85-101. [CrossRef]

50. Li, J.G.; Batten, D.J. Early Cretaceous palynofloral provinces in China: Western additions. Isl. Arc 2010, 20, 35-42. [CrossRef]

51. Jin, P.; Ji, L.; Ma, B.; Yuan, B.; Long, L. Early Cretaceous palynology and paleoclimate of the Hanxia-Hongliuxia Area, Jiuxi Basin, China. Rev. Palaeobot. Palynol. 2020, 281, 104259. [CrossRef]

52. Van Konijnenburg-Van Cittert, J.H.A. Ecology of some Late Triassic to Early Cretaceous ferns in Eurasia. Rev. Palaeobot. Palynol. 2002, 119, 113-124. [CrossRef]

53. Couper, R.A. British Mesozoic microspores and pollen grains. A systematic and stratigraphic study. Palaeontogr. Abt. B 1957, 103, 75-179.

54. Balme, B.E. Fossil in situ spores and pollen grains: An annotated catalogue. Rev. Palaeobot. Palynol. 1995, 87, 81-323. [CrossRef]

55. Kovaleva, T.A.; Markevich, V.S.; Sun, G. Age and palynological characteristic of the Dongning Formation (Eastern Heilongjiang, China). Russ. J. Pac. Geol. 2017, 11, 178-190. [CrossRef]

56. Wan, C.; Qiao, X.; Kong, H.; Jin, Y.; Sun, Y.; Liu, P.; Yang, J.; Ren, Y. Early Cretaceous spore-pollen assemblage from Bei'an area, Heilongjiang Province. Acta Micropalaeontol. Sin. 2002, 19, 83-90.

57. Simoneit, B.R.T.; Grimalt, J.O.; Wang, T.G.; Cox, R.E.; Hatcher, P.G.; Nissenbaum, A. Cyclic terpenoids of contemporary resinous plant detritus and fossil woods, ambers and coals. Org. Geochem. 1986, 10, 877-889. [CrossRef]

58. Stefanova, M.; Markova, K.; Marinov, S.; Simoneit, B.R.T. Molecular indicators for coal-forming vegetation of the Miocene Chukurovo lignite, Bulgaria. Fuel 2005, 84, 1830-1838. [CrossRef]

59. Diefendorf, A.F.; Freeman, K.H.; Wing, S.L. A comparison of terpenoid and leaf fossil vegetation proxies in Paleocene and Eocene Bighorn Basin sediments. Org. Geochem. 2014, 71, 30-42. [CrossRef]

60. Bechtel, A.; Chekryzhov, I.Y.; Pavlyutkin, B.I.; Nechaev, V.P.; Dai, S.; Vysotskiy, S.V.; Velivetskaya, T.A.; Tarasenko, I.A.; Guo, W. Composition of lipids from coal deposits of the Far East: Relations to vegetation and climate change during the Cenozoic. Palaeogeogr. Palaeoclimatol. Palaeoecol. 2020, 538, 109479. [CrossRef]

61. Otto, A.; Walther, H.; Püttmann, W. Sesqui- and diterpenoid biomarkers in Taxodium-rich Oligocene oxbow lake clays Weisselster basin, Germany. Org. Geochem. 1997, 26, 105-115. [CrossRef]

62. van Aarssen, B.G.K.; Cox, H.C.; Hoogendoorn, P.; de Leeuw, J.W. A cadinene biopolymer present in fossil and extant dammar resins as a source for cadinanes and bicadinanes in crude oils from Southeast Asia. Geochim. Cosmochim. Acta 1990, 54, 3021-3031. [CrossRef]

63. Philp, R.P. Fossil Fuel Biomarkers Methods in Geochemistry and Geophysics; Elsevier: New York, NY, USA, 1985; Volume 23, pp. 1-294. 
64. Fabiańska, M.J.; Kurkiewicz, S. Biomarkers, aromatic hydrocarbons and polar compounds in the Neogene lignites and gangue sediments of the Konin and Turoszów Brown Coal Basins (Poland). Int. J. Coal Geol. 2013, 107, 24-44. [CrossRef]

65. Wakeham, S.G.; Schaffner, C.; Giger, W. Polycyclic aromatic hydrocarbons in recent lake sediments-II. Compounds derived from biogenic precursors during early diagenesis. Geochim. Cosmochim. Acta 1980, 44, 415-429. [CrossRef]

66. Otto, A.; Wilde, V. Sesqui-, di-, and triterpenoids as chemosystematic markers in extant conifers-a review. Bot. Rev. 2001, 67, 141-238. [CrossRef]

67. Hauke, V.; Graff, R.; Wehrung, P.; Trendel, J.M.; Albrecht, P.; Schwark, L.; Keely, B.; Peakman, T. Novel triterpene-derived hydrocarbons of the arborane/fernane series in sediments Part I. Tetrahedron 1992, 48, 3915-3924. [CrossRef]

68. Hauke, V.; Graff, R.; Wehrung, P.; Trendel, J.M.; Albrecht, P.; Riva, A.; Hopfgartner, G.; Gülacar, F.O.; Buchs, A.; Eakin, P.A. Novel triterpene-derived hydrocarbons of the arborane/fernane series in sediments: Part II. Geochim. Cosmochim. Acta 1992, 56, 2595-3602. [CrossRef]

69. Brassell, S.C.; Eglinton, G. Steroids and Triterpenoids in Deep Sea Sediments as Environmental and Diagenetic Indicators. In Advances in Organic Geochemistry; John Wiley and Sons: Hoboken, NJ, USA, 1981; Volume 2, pp. 684-697.

70. Volkman, J.K.; Allen, D.I.; Stevenson, P.L.; Burton, H.R. Bacterial and algal hydrocarbons from a saline Antarctic lake, Ace Lake. Org. Geochem. 1986, 10, 671-681. [CrossRef]

71. Gruber, W.; Sachsenhofer, R.F. Coal deposition in the Noric Depression (Eastern Alps): Raised and low-lying mires in Miocene pull-apart basins. Int. J. Coal Geol. 2001, 48, 89-114. [CrossRef]

72. Opluštil, S.; Pšenicka, J.; Libertín, M.; Bek, J.; Dašková, J.; Šimunek, Z.; Drábková, J. Composition and structure of an in situ Middle Pennsylvanian peat-forming plant assemblage buried in volcanic ash, Radnice Basin (Czech Republic). Palaios 2009, 24, 726-746. [CrossRef]

73. Wu, H.; Hu, Z. Comparative anatomy of resin ducts of the Pinaceae. Trees-Struct. Funct. 1997, 11, 135-143. [CrossRef]

74. Grimalt, J.O.; Simoneit, B.R.T.; Hatcher, P.G. Chemical affinities between the solvent extractable and the bulk organic matter of fossil resin associated with an extinct podocarpaceae. Phytochemistry 1989, 28, 1167-1171. [CrossRef]

75. Simoneit, B.R.T.; Cox, R.E.; Oros, D.R.; Otto, A. Terpenoid Compositions of Resins from Callitris Species (Cupressaceae). Molecules 2018, 23, 3384. [CrossRef] [PubMed]

76. Heady, R.D.; Banks, J.G.; Evans, P.D. Wood anatomy of Wollemi pine (Wollemia nobilis, Araucariaceae). IAWA J. 2002, 23, 339-357. [CrossRef]

77. Wilkins, R.W.T.; George, S.C. Coal as a source rock for oil: A review. Int. J. Coal Geol. 2002, 50, 317-361. [CrossRef]

78. Shao, L.; Zhang, P.; Hilton, J.; Gayer, R.; Wang, Y.; Zhao, C.; Luo, Z. Paleoenvironments and paleogeography of the Lower and lower Middle Jurassic coal measures in the Turpan-Hami oil-prone coal basins, northwestern China. AAPG Bull. 2003, 87, 335-355. [CrossRef] 